\title{
SLIPPER ORCHIDS IN ART AND SCIENCE
}

\author{
PHILLIP CRIBB \\ Royal Botanic Gardens, Kew, Richmond, Surrey TW9 3AB, United Kingdom \\ P.Cribb@kew.org
}

\begin{abstract}
The lady's slippers, orchids with showy and unusual flowers with considerable diversity in shape, size and colour, are amongst the most popular of all orchids in science and horticulture. Consequently, the botanical and horticultural literature on them is extensive. Artists and designers have also been intrigued by them and they feature in many illustrated botanical and horticultural books and decorative items, from tapestries to porcelain and stamps. In this article, the history of slipper orchids is illustrated by reference to illustrations of them, mostly in the collections of the Royal Botanic Gardens. Kew.
\end{abstract}

Key words: Orchidaceae, Cypripedioideae, botanical illustration, Kew

"Be guided by nature". "Do not depart from it, thinking that you can do better yourself"

Albrecht Dürer (1471-1528)

"Modern botanical drawing may ... be said to date from the publication in 1530 of Brunfels' Herbarum Vivae Eicones"

Wilfred Blunt \& William Stearn

The Art of Botanical Illustration (1994)

Introduction. Modern botany has its origins in Ancient Greece (Arber, 1986; Pavord, 2005). The first herbal, describing and naming plants of use to physicians was prepared in the eastern Mediterranean by a student of Plato, the Greek physician Theophrastus of Lesbos (371-287 BC) (Arber, 1986). Much of the knowledge in his Enquiry into Plants and On the causes of Plants was distilled by Dioscorides (40-90 AD) in his De Materia Medica, a text that was copied and widely used by physicians for the following 1500 years. The earliest surviving copy is the Codex Julian Anicia of $512 \mathrm{AD}$, prepared for Juliana Anicia, the daughter of the Emperor Anicius Olybrius in Constantinople and preserved in the Austrian National Library in Vienna. Amazingly, this copy of Dioscorides' herbal is illustrated in colour with life-like and recognisable images of plants from the region. The significance of illustrations can be traced to the ease with which they can be used for identification purposes when compared with the written word. In essence, they make the process of identification and naming much quicker and easier. Images of orchids do not appear in the Codex, but first appeared in the new herbals that began to be published in the Renaissance.

Botanical art made its greatest impact with the publication of the first printed herbals. According to Wilfred Blunt and William Stearn (1994), "Modern botanical drawing may ... be said to date from the publication in 1530 of Brunfels' Herbarum Vivae Eicones". Otto Brunfels' herbal was illustrated with fine woodcuts based on original drawings by Hans Weiditz, a pupil of Albrecht Durer. Weiditz's originals survive in the herbarium of Felix Platter (Figs 1, 2), preserved in the City Library in Bern. Brunfels' herbal

* This paper was prepared in the framework of the celebration of Lankester Botanical Garden's $40^{\text {th }}$ anniversary. Charles Lankester formed a close association with Victor Summerhayes, Kew's orchid specialist from 1928 until his retirement in 1964. They he corresponded frequently and Lankester sent many living and preserved plants to Kew that he could not identify. This relationship contributed many rarities to the Kew orchid herbarium and living collections over the years and enabled Lankester to provide identities and names for his many discoveries which he grew on in his private garden which is now the Jardin Botanico Lankester. The relationship between the botanists there and at Kew continues fruitfully to the present day. It is a pleasure to contribute this article to the celebration of Charles Lankester's legacy which is now a thriving source of expertise on Costa Rica's rich native flora 


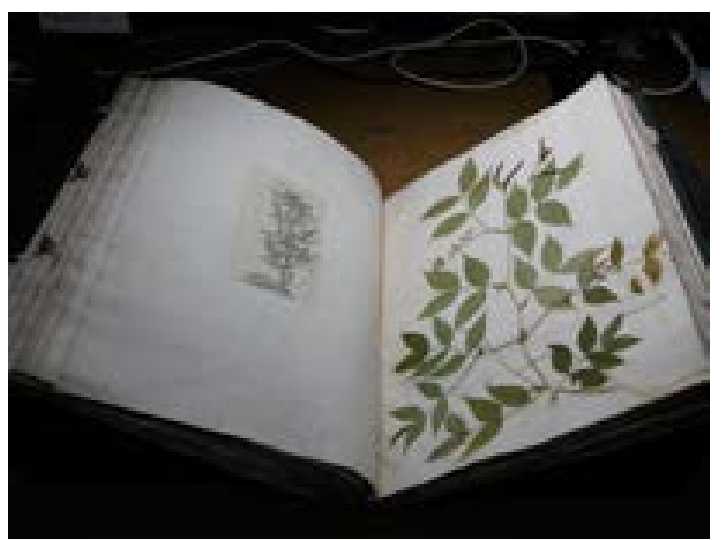

FiguRe 1. Felix Platter herbarium volume. Courtesy of the Historical Museum of Bern.

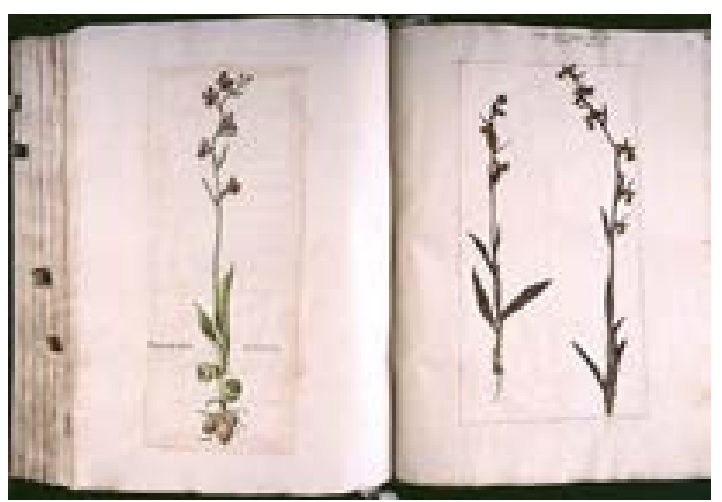

FiguRE 2. Orchids in the Felix Platter herbarium. Courtesy of the Historical Museum of Bern.

included orchids, although no lady's slipper, a surprise because it is native and not uncommon in Germany. We have to wait until later in the $16^{\text {th }}$ century for slipper orchids or lady's slippers to make their first appearance in literature and illustration. Let us, first of all, consider what distinguishes the lady's slipper orchids.

Slipper orchids. Lady's slippers, comprising about 160 species (Pridgeon et al., 1999), are found throughout Asia, Europe and the Americas as far south as Bolivia and Brazil, but are absent from Africa, Madagascar and Australia. They are among the most popular of orchids. The earliest record we have of their cultivation is that by Philip Miller in 1731. He grew the native Lady's slipper orchid (Cypripedium calceolus) at the Chelsea Physic Garden. Nowadays, no collection is complete without its selection of slipper orchids.

Lady's slippers have features that set them apart from other orchids, and form a distinct well-defined group within the family, distinguished by the flowers which have lateral sepals joined to form a synsepal, a slipper-shaped lip termed, two fertile lateral anthers of the inner whorl, a sterile more or less shield-shaped staminode at the apex of the column, and a stalked trilobed stigma that lies ventrally on the column behind the staminode. Consequently, they have been considered to be "primitive" orchids. They represent as small percentage of the family Orchidaceae, certainly less than $1 \%$ in terms of numbers of species and genera. Furthermore, many are rare and threatened with extinction in their native habitats.

Slipper orchids are now recognised as a distinct subfamily, the Cypripedioideae, within the Orchidaceae (Dressler 1981, 1993, Chase et al., 2003), comprising five genera. All slipper orchids were included in the genus Cypripedium for almost a century after the name was established by Linnaeus (1737). Constantine Samuel Rafinesque $(1819,1838)$, who knew the hardy American species at first hand, was the first to recognise the diversity within the slipper orchids, establishing the genera Sacodon, Stimegas, Cordula, Menophora and Criosanthes but his work was largely ignored by his contemporaries because it was published in obscure and little circulated works and he was less than clear himself about the status of his taxa.. Of these names Sacodon and Criosanthes refer to species now included in Cypripedium, while the rest refer to species now included in Paphiopedilum which has been conserved over Cordula and Stimegas (Farr et al. 1979).

H. G. Reichenbach (1854) established the genus Selenipedium for the tropical American species which have a trilocular ovary. Blume (1858) discounted this character because he found unilocular ovaries of some species were trilocular towards each end. However, George Bentham and Joseph Hooker (1883) followed Reichenbach in dividing the slipper orchids into two genera.

Ernst Pfitzer (1886, 1889, 1894) prepared the ground for the modern generic treatment of the slipper orchids by recognising the correlation of leaf type with perianth persistence. He established the genus Paphiopedilum for the tropical Asiatic and American species with hard leaves and a deciduous perianth, leaving the plicate-leaved northern temperate species with a persistent perianth in Cypripedium and the tropical American ones in Selenipedium.

Robert Rolfe (1896) revised the slipper orchids. He 


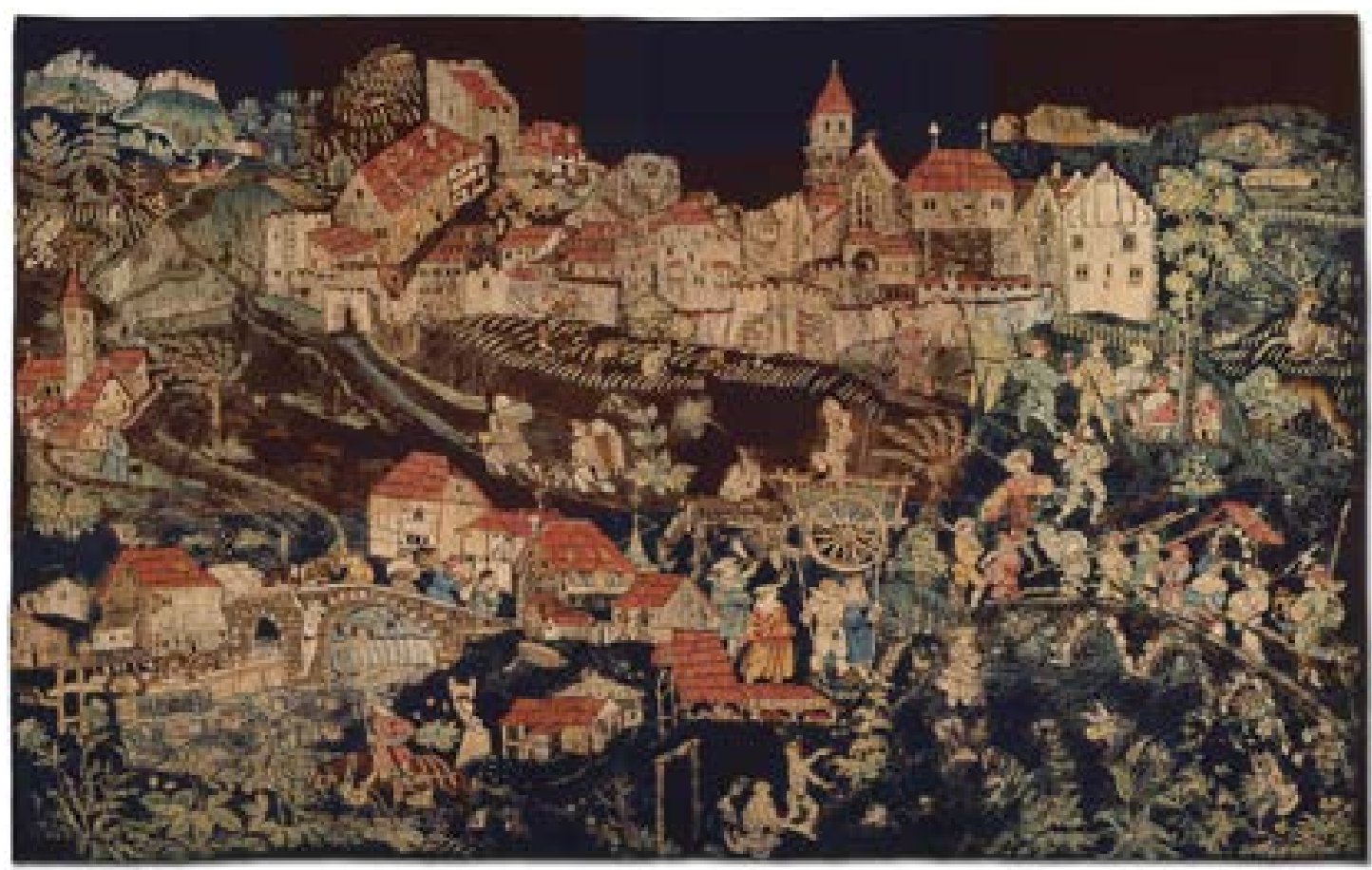

Figure 3A. The Bischofzell tapestry, Basel City Museum, showing Cypripedium calceolus in the lower part. Courtesy of the Basel City Museum.

restricted the genus Paphiopedilum (now c. 70 species) to the Old World hard-leaved species with imbricate imbrications, but placed the New World hard-leaved species in a new genus Phragmipedium (now ca. 21 species) based on their leaf type and valvate imbrication of the sepals. The use of Cypripedium (now 47 species) and Selenipedium (now 5 species) followed that of Pfitzer.

The monotypic Mexipedium, the fifth slipper orchid genus, was established by Albert and Chase (1992) to accommodate a dwarf Mexican slipper orchid which had morphological features intermediate between those of the tropical American Phragmipedium and the tropical Asiatic Paphiopedilum. It was originally included by Soto et al. (1990) in Phragmipedium on account of its possession of the valvate aestivation of its sepals, the absence of sinuous epidermal cells in the perianth, the fusion of the side lobes of its lip and the ventral synsepal being larger than the dorsal sepal. Albert and Chase added a further character of branched inflorescences in Phragmipedium but absent from Paphiopedilum. Two years later, with the benefit of data from DNA analysis, Albert (1994) found that
Mexipedium was basal in the Phragmipedium clade.

Slipper orchids have also fascinated generations of botanists. Notably, their pollination biology was first studied by Charles Darwin, the pre-eminent biologist. They have consequently featured prominently in botanical art. Here, the history of slipper orchids in art is considered and illustrated by some of the fine illustrations and representations that are in the collections of the Royal Botanic Gardens, Kew

\section{Illustrations of slipper orchids}

Cypripedium -. "Cypripediums - The grandest and most august of the Orchidaceae, one great race which is supreme alike in the open and under cover, deserves full treatment by itself."

Reginald Farrer (1919) in The English Rock Garden

In the subdued light in the basement of the Historisches Museum Basel hangs a remarkable tapestry which depicts a summer scene of the small walled town of Bischofszell in north-eastern Switzerland just south of the Bodensee (Lake Constance) (Fig. 3A). The tapestry dates from 1510 and, for the botanist, 


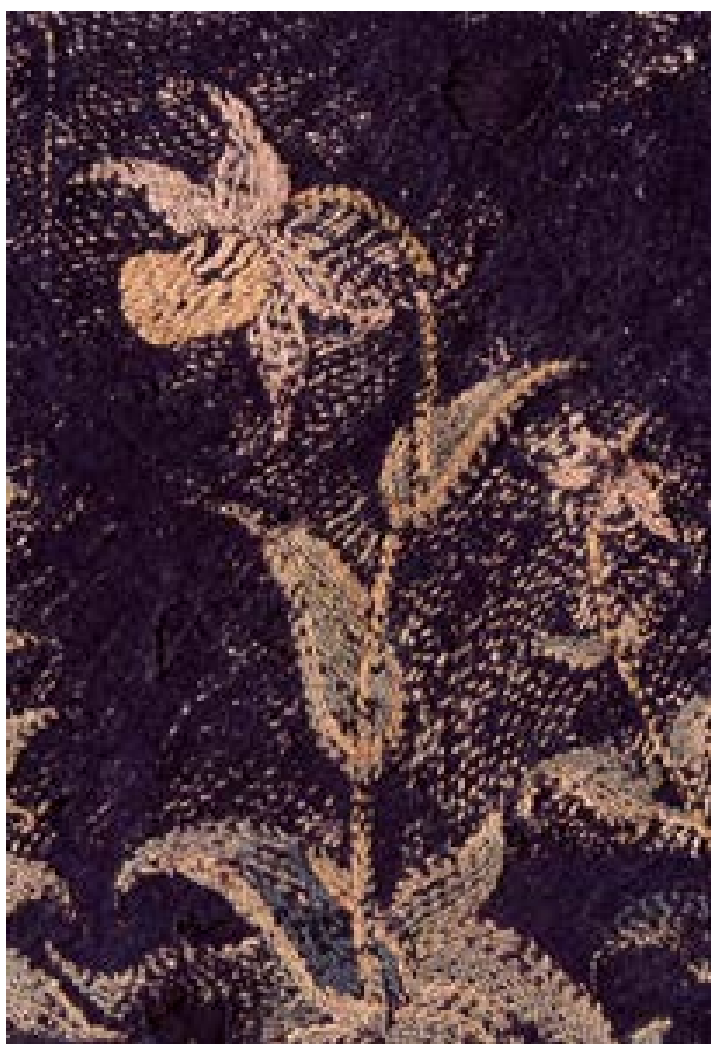

Figure 3B The Bischofzell tapestry, Basel City Museum. Detail od Cypripedium calceolus. Courtesy of the Basel City Museum.

its beauty is enhanced by the accurate depiction of a number of native plants, including oxlip, columbine, wild strawberry and a lady's slipper orchid (Fig. 3B). This may well be its first depiction. The slipper orchid image is situated on the lower border slightly to the right of centre and shows a yellow-flowered plant, not the normal form which has a yellow pouch and maroon sepals and petals. However, plants with pure yellow of almost yellow flowers do occasionally occur in populations of more typical plants in Switzerland.

Linnaeus first used the name Cypripedium in 1737 in his Flora Lapponica in describing the European species as "Cypripedium foliis ovato-lanceolatis", the name Cypripedium alluding to Cyprus, the island that was the mythological birthplace of Aphrodite (Venus), and "pedilum" a shoe or slipper, in allusion to the popular name of "Lady's slipper". In 1753 he named and described two species C. calceolus and $C$. bulbosum. The former concept included the well-known

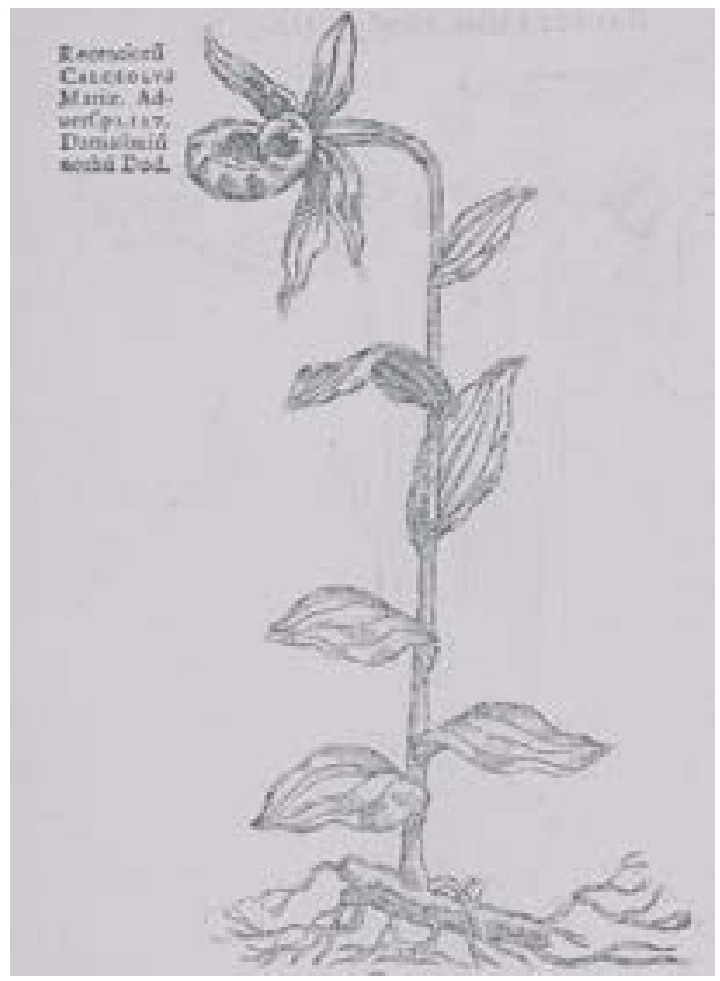

Figure 4. Rembert Dodoens' illustration of Cypripedium calceolus in his Florum, et coronarium odoratarumque nonnullarum herbarium historia (1568). Reproduced with the kind permission of the Director and the Board of Trustees, Royal Botanic Gardens, Kew.

European C. calceolus and the North American species now treated as C. parviflorum (var.b), C. acaule (var.g), and $C$. guttatum (var.d). The last is now considered to belong to the distinct and unrelated genus Calypso.

Linnaeus was by no means the first to describe slipper orchids. The earliest description and published illustration of a slipper orchid can be traced to the herbal of Rembert Dodoens (1568) entitled Florum, et coronarium odoratarumque nonnullarum herbarium historia. His wood-cut illustration of "Damasonium nothum" or "Papen schoen", a one-flowered plant of C. calceolus complete with rhizome and roots (Fig. 4), is simple but accurate and clearly identifiable. The drawing was sent to him by Joannes Vreccomtus of Brussels who had flowered the illustrated plant in his garden, the earliest record of its cultivation.

Mathias de L'Obel (1576) reproduced Dodoens' illustration in his Plantarum seu stirpium historia while Dodoens (1583) used it again in his Stirpium historiae 


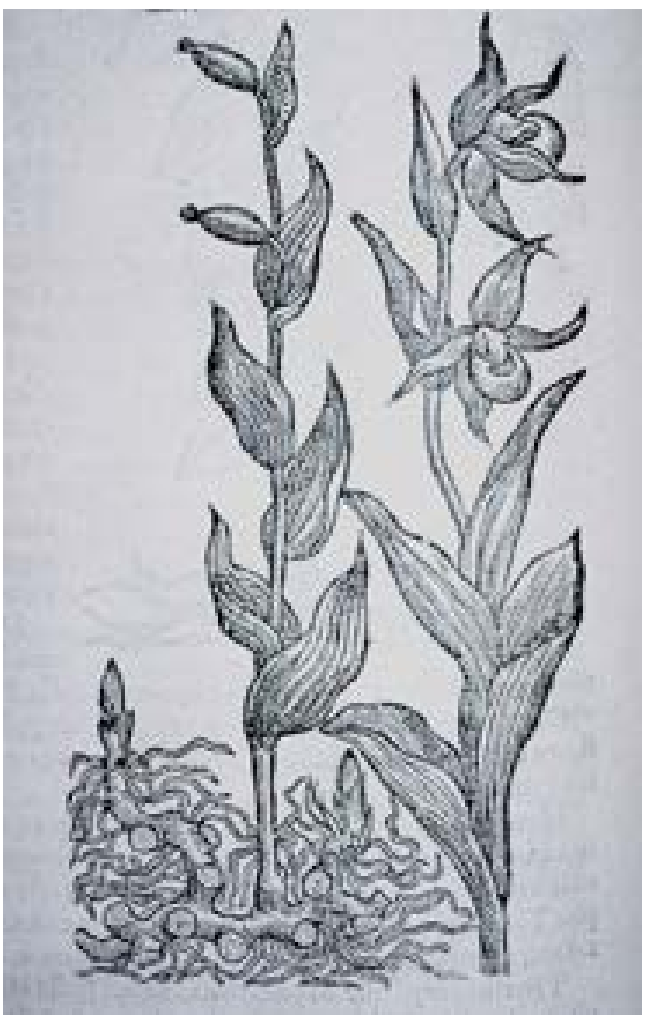

FIGURE 5. Cypripedium calceolus from Dodoens' herbal Stirpium historiae pemptades (1583). Reproduced with the kind permission of the Director and the Board of Trustees, Royal Botanic Gardens, Kew.

pemptades... together with a more refined illustration of a plant with a branched rhizome with several shoots, one of which bears two flowers and the other two seed pods (Fig. 5). The latter originated in the contemporary herbal Rariorum aliquot stirpium... of Charles de L'Ecluse (1583), also known as Clusius. Dodoens used the name "Calceolus Marianus", "Pfaffen schuh", "Papen schoen" and "Calceolus Sacerdotis", while Clusius, "referring to it as "Marienschuh", placed it next to the helleborines, "Elleborine ". Dodoens stated that it was found in "Helvetiorum, \& Norici, ac Pannoniae superioris sive Austriae montibus". Clusius had seen the plant in the wild in Austria and Hungary and it seems likely that his illustration was based on a wild plant seen on his travels. The wood-cut would then have been produced for his own work but shared with Dodoens who was a good friend (Arber,1986).

Dodoens' plate reappears in several later herbals, notably those of John Gerard (1597) in his Herball and John Parkinson (1629) in his Paradisi in sole paradisus terrestris... Large chunks of Dodoens' work appear in Gerard's Herbal in translation. However, this was an accepted methodology of the day and Gerard did add notes on plants with which he was familiar. He calls Cypripedium calceolus "Our Ladies shooe or slipper" and notes that it "groweth upon the mountains of Germanie, Hungarie, and Poland". He grew a plant given to him by his friend the Apothecary Master Garret and this is the earliest reference I can trace of the cultivation of the species in the British Isles. It is interesting that Gerard was unaware that it was a native British species. Its recognition as such was left to John Parkinson (1629) who called it "Helleborine vel Elleborine maior, sive Calceolus Mariae".

Parkinson recorded it as growing in "Lancashire, neare the border of Yorkshire, in a wood or place called the Helkes, which is three miles from Inglborough, the higest Hill in England, and not farre from Ingleton, as I am informed by a courteous Gentlewoman, called Mistris Thomasin Turnstall, who dwelleth at Bullbanke, near Hornby Castle...(she) hathe often sent mee up the rootes to London which have faire flowers in my Garden”. The Lady's Slipper survived in that area until into the present century and Parkinson's only mistake is his suggestion that Ingleborough is the highest hill in England. Parkinson was indeed an astute observer and noted that the seed of C. calceolus "is very small, very like unto the seede of the Orchides or Satyrions, and contained in such like long pods, but bigger." As far as I can determine he was the first to connect Cypripedium with the orchids and to note their tiny seeds. Michel Adanson (1763) was the first botanist to formally include slipper orchids in the orchid family.

The earliest known colour illustration of $C$. calceolus is that by Conrad Gesner (or Gessner) dating from 1541, a watercolour of a plant from Mt. Saleu in the Swiss Jura near Geneva (Fig. 6). It is an accomplished likeness, far superior to the later woodcuts in the L'Obel, Dodoens and Clusius herbals, while in botanical accuracy and detail of the rhizome, fruit and column it was not matched for another two hundred or more years. Gesner died from plague before he was able to publish his botanical illustrations. Schmiedel (1754-1759) published part of Gesner's botanical work for the first time as Opera Botanica and included the coloured illustration and account of C. calceolus as "Calceolus Mariae". They 


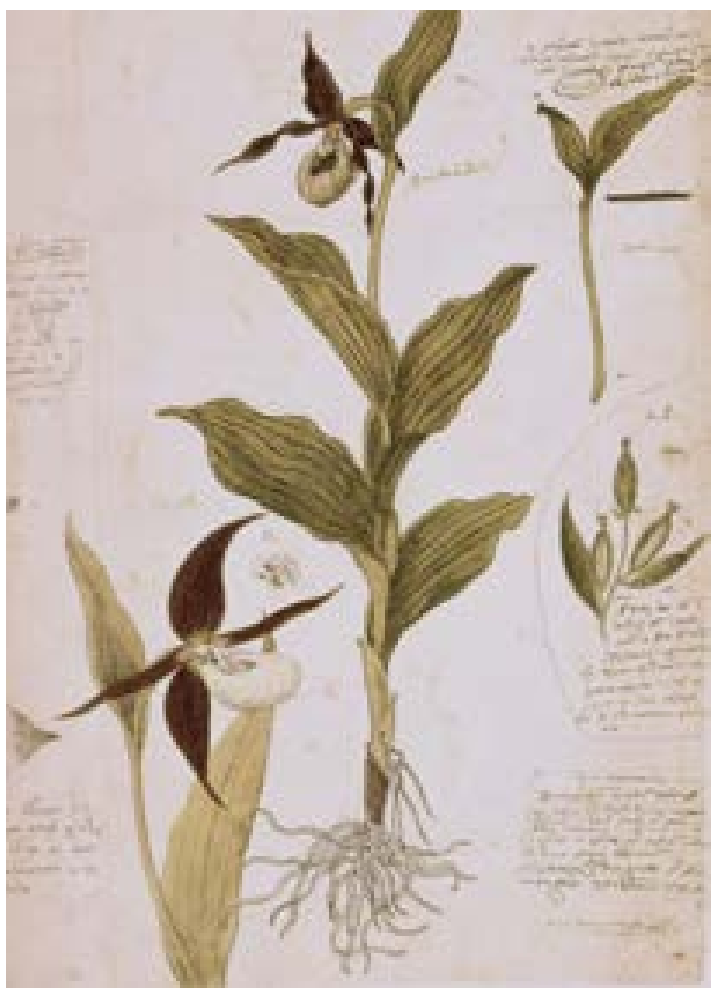

FiguRe 6. Conrad Gesner's illustration of Cypripedium calceolus, ca. 1540. Reproduced with the kind permission of the Director and the Board of Trustees, Royal Botanic Gardens, Kew.

have recently been reproduced in facsimile by Zoller, Steinmann \& Schmidt (1973-1980). A useful list of early descriptions and illustrations of slipper orchids is included.

Another early colour illustration of $C$. calceolus is that by Daniel Rabel (1578-1638), recently reproduced in the second edition of Blunt \& Stearn (1994). The original is in the Bibliotheque Nationale in Paris and it was probably painted in 1631 or 1632 .

Parkinson (1640) returned to the theme of "Our Ladyes Slipper or the great wilde Helleborine" in his Theatrum botanicum. There he recorded a North American species, undoubtedly $C$. reginae, as a "sort thereof.......brought from the North parts of America, differing onely in being greater both in stalkes, leaves and flowers, which are not yellow but white, with reddish strakes through the bellies of them". An earlier reference to a North American species, however, is that of J.P. Cornut (1635) in his Canadensium Plantarum Historia

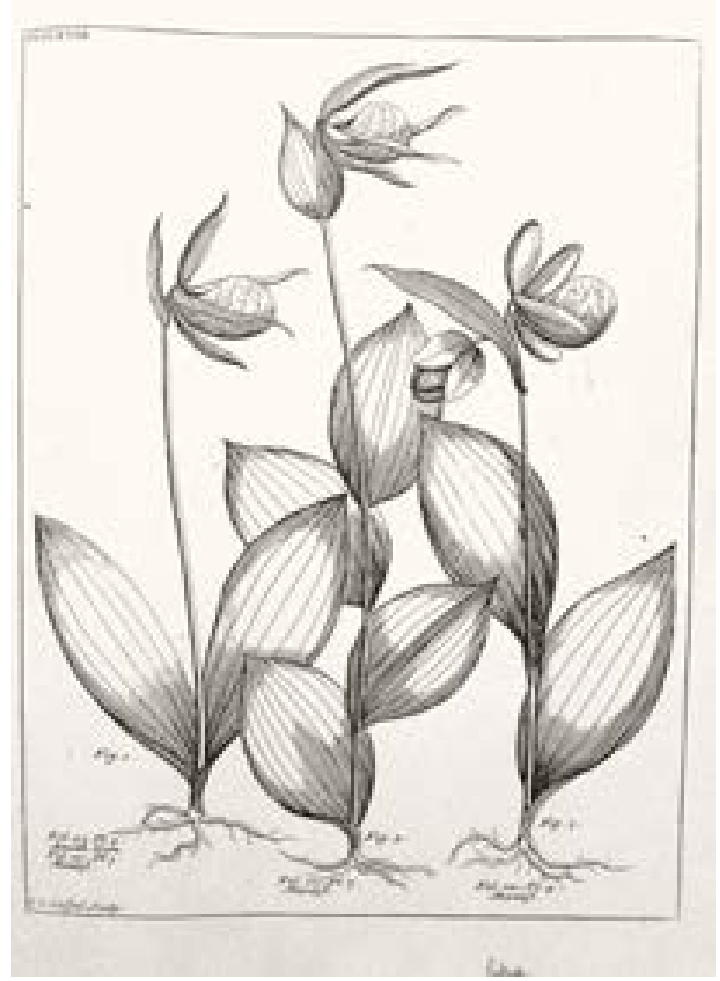

Figure 7. Leonard Plukenet's plate of $C$. acaule and $C$. parviflorum var. parviflorum and var. pubescens from his Amaltheum Botanicum (1700). Reproduced with the kind permission of the Director and the Board of Trustees, Royal Botanic Gardens, Kew.

where he listed "Calceolus marianus canadensis", a reference to $C$. acaule, the Moccasin flower.

Cypripedium reginae and three other North American taxa, C. acaule and C. parviflorum var. parviflorum ("Calceolus...flore luteo minore") and var.pubescens, were described by Leonard Plukenet (1700) in his Mantissa, the first two and the last being illustrated by him in 1705 in his Amaltheum Botanicum (Fig. 7). These line illustrations are the earliest representations of North American slipper orchids. The earliest coloured illustration of a North American species is that of "Calceolus flore maximo rubente" $(=C$. acaule) (Fig. 8) by Mark Catesby (1754) in The Natural History of Carolina, Florida and the Bahama Islands.

The first edition of Philip Miller's Gardeners Dictionary, published in 1731, included three species of hardy slipper orchid: the European species as "Helleborine; flore rotundo, sive Calceolus"; 


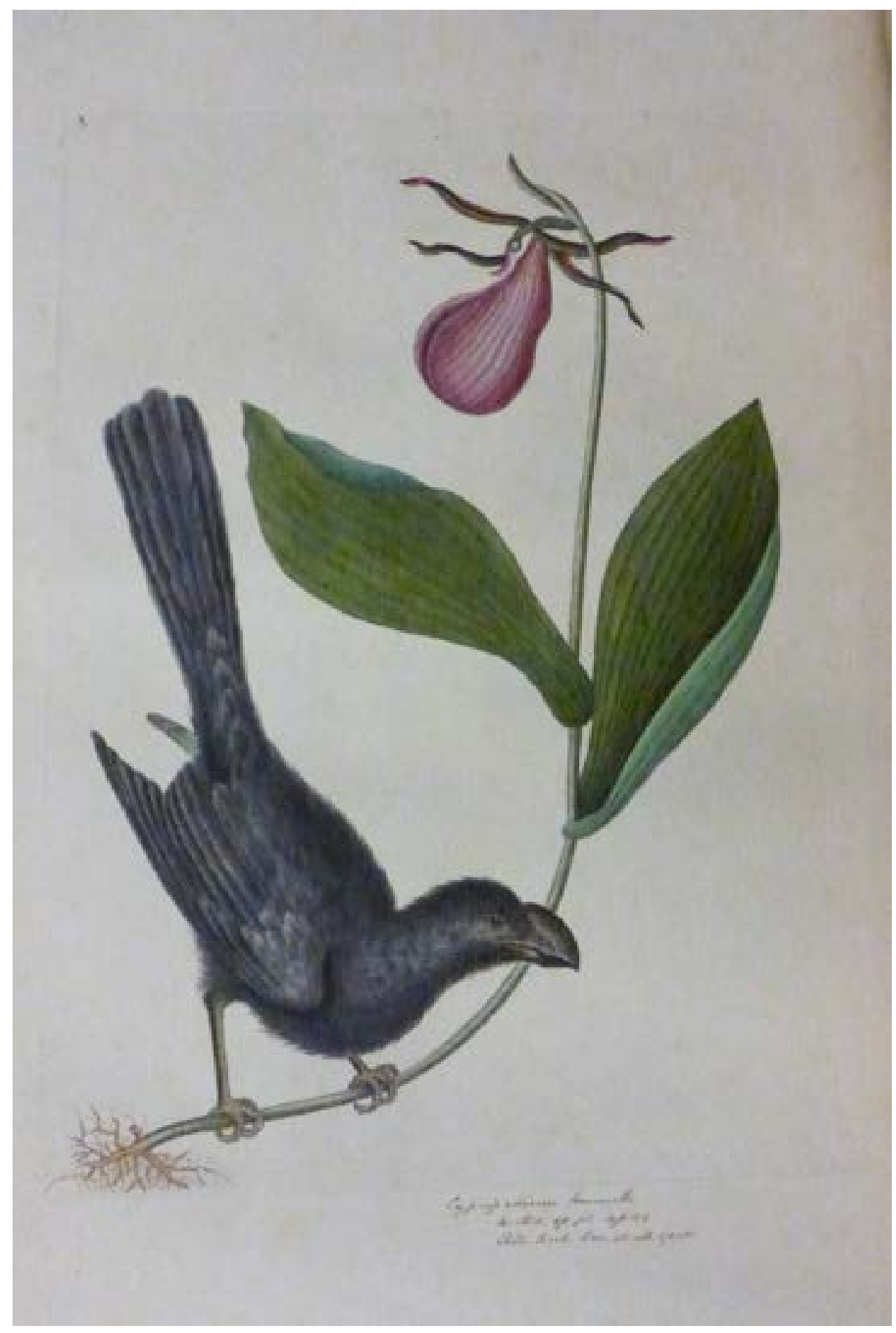

FIgURE 8. Mark Catesby's illustration of Cypripedium acaule from The Natural History of Carolina, Florida and the Bahama Islands (1754). Reproduced with the kind permission of the Director and the Board of Trustees, Royal Botanic Gardens, Kew. 


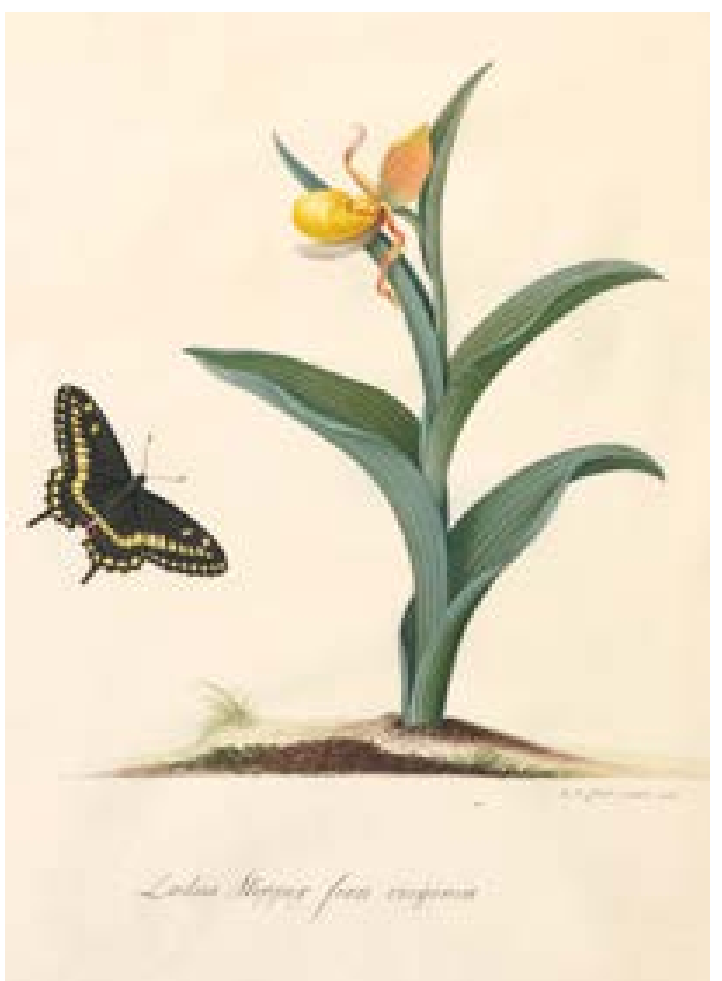

FIGURE 9. Cypripedium parviflorum var. pubescens by Georg Dionysius Ehret, ca. 1758. Reproduced with the kind permission of the Director and the Board of Trustees, Royal Botanic Gardens, Kew.

and two North American species "Helleborine; Virginiana, flore rotundo luteo", one of the varieties of C. parviflorum, and "Helleborine; Canadensis, sive calceolus mariae", probably $C$. reginae. He commented that "all (are) Natives of Woody and shady Places". He provided a coloured illustration in his Figures of the most beautiful, useful and uncommon plants figured in the Gardeners Dictionary published in 1758. This illustration may, indeed, be the first of a British plant as Miller reiterates that it was "found in some Parts of England" and also mentions flowering it at Chelsea where, no doubt, the coloured illustration by R. Lancake was made. The German artist Georg Dionysius Ehret who worked at the Chelsea Physic Garden for Miller also illustrated a plant of the North American C. parviflorum var. pubescens (Fig. 9) which Miller probably grew at Chelsea.

Linnaeus (1753) apparently overlooked Parkinson's and Miller's references to North American species

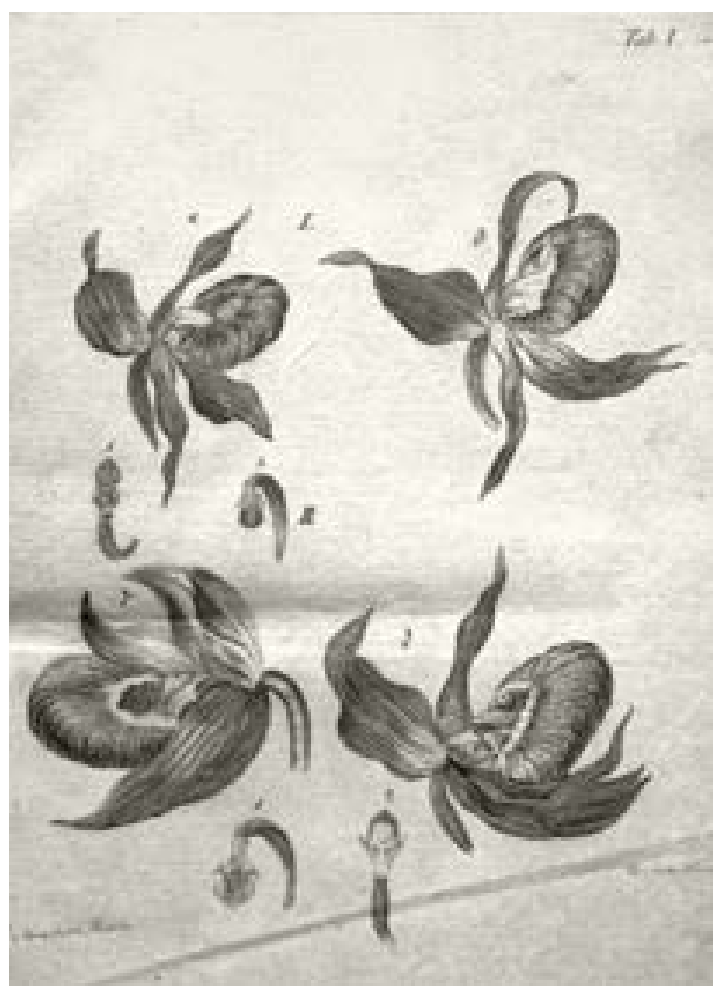

FigURE 10. Plate of Cypripedium calceolus, C. macranthos and $C . \mathrm{x}$ ventricosum from Gmelin's Flora Sibirica (1747-1749). Reproduced with the kind permission of the Director and the Board of Trustees, Royal Botanic Gardens, Kew.

but including Cornut and Morison's names within $C$. calceolus, the European species which must have been familiar to him in his native Sweden.

William Aiton (1789) listed three species in his Hortus Kewensis: the European C. calceolus, and the North American C. reginae (as C. album) and $C$. acaule as being grown at Kew. C. reginae had been introduced by William Hamilton in 1786 and C. acaule by William Young in 1770.

Johann Amman (1741) and Johann Georg Gmelin (1747-1749) published the first descriptions and illustrations of Asian slipper orchids (Fig. 10). The former illustrated Siberian C. macranthos as "Calceolus purpureus speciosus"and C. guttatum as "Calceolus minor flore vario". The latter figured $C$. calceolus, C. ventricosum and C. macranthos, the last as "Calceolus purpureis speciosus". Swartz (1800) based the names $C$. ventricosum and $C$. macranthos on Gmelin's collections. 


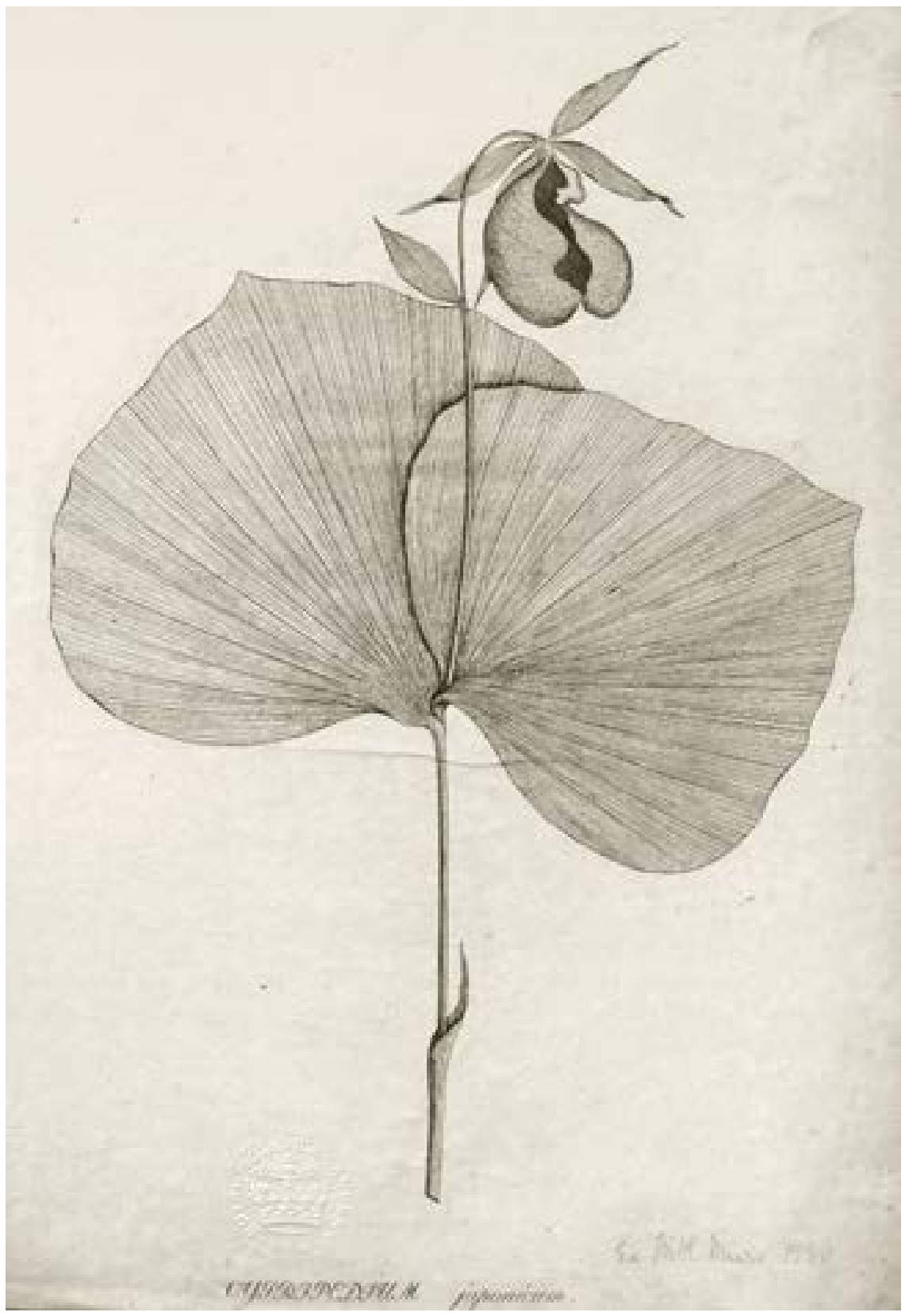

FIGURE 11. Carl Peter Thunberg's illustration of Cypripedium japonicum from his Flora Japonica (1784). Reproduced with the kind permission of the Director and the Board of Trustees, Royal Botanic Gardens, Kew.

Linnaeus's pupil Carl Peter Thunberg was the first western botanist to visit Japan. Cypripedium japonicum and C. macranthos (as C. calceolus) were described in his Flora Japonica (1784), the former also being illustrated there (Fig. 11). The Japanese slipper orchids C.japonicum, C. debile and C. macranthos figured in Yokusai Iinuma's
Somoku Zusetsu of 1874. However, Ludovic Savatier's watercolours of $C$. japonicum and C. macranthos made between 1856 and 1866 survive in the Kew collection. Most of the species in the Far East remained unknown for nearly a century more until botanists began to penetrate into the mountainous west of China. 


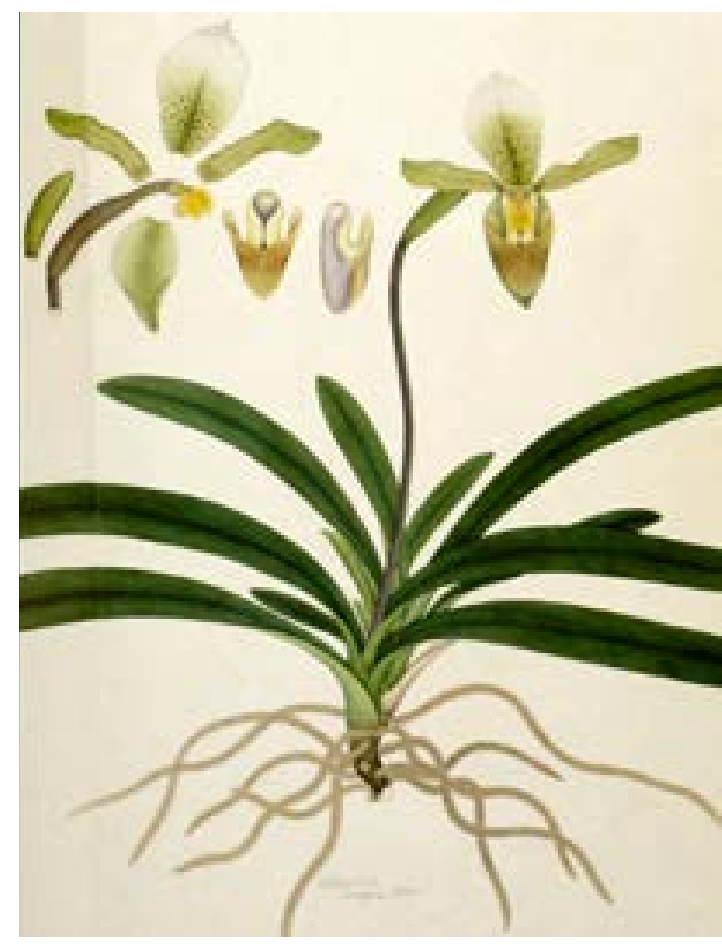

FiguRe 12. Paphiopedilum insigne by an unknown Indian artist for the Calcutta Botanic Garden, ca. 1820. Reproduced with the kind permission of the Director and the Board of Trustees, Royal Botanic Gardens, Kew.

The first hint of the rich array of western Chinese Cypripedium species was the collection in 1864 by Père Armand David of the yellow-flowered C. luteum (now C. flavum) at Moupin in what is now western Sichuan. However, the diversity of the Chinese cypripediums was not apparent until the last few years of the 19th century. From 1894 onwards, the indefatigable French missionaries, Delavay, Soulie, Maire, Monbeig and Farges, based in Yunnan and Sichuan, began to send back large numbers of collections to Paris, many to be described as new to science by the French botanist Franchet. By the turn of the century the British collectors Augustine Henry in Hubei, Sichuan and Yunnan and Ernest Wilson in Sichuan and Hubei had added further species. New Chinese species have continued to be discovered and described this century (Tang \& Wang, 1951; Cribb, 1992; Cribb \& Chen, 1994; Chen et al., 2013) and many have been illustrated in Curtis's Botanical Magazine, founded in 1878 and the oldest surviving journal illustrated in colour.

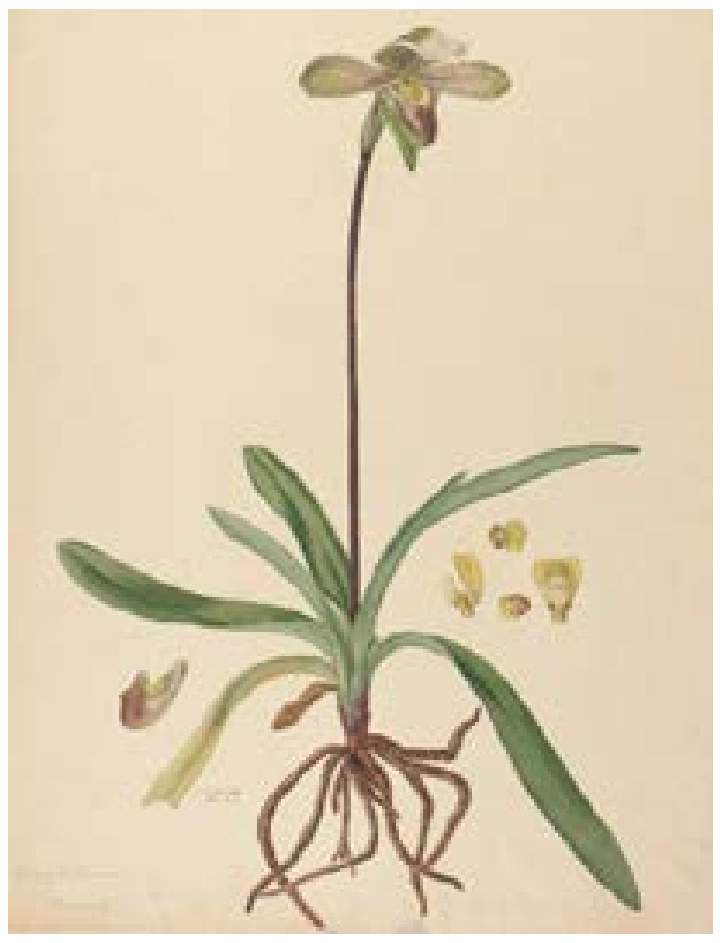

FIgURe 13. Samuel Curtis's Paphiopedilum insigne drawn for John Lindley's Collectanea Botanica (1821). Reproduced with the kind permission of the Director and the Board of Trustees, Royal Botanic Gardens, Kew.

Paphiopedilum - The increasing influence of the British in India opened up its rich tropical flora to botanists and horticulturists. The establishment of botanic gardens, initially to introduce crops for plantation culture, led to the flora being explored by a number of intrepid collectors and botanists, particularly those associated with the Calcutta Botanic Garden which had been established in 1787. William Roxburgh collected orchids and employed Indian artists to draw them. Nathaniel Wallich, his successor, developed the garden and started the herbarium of the East India Company, the latter being the basis of our current knowledge of the flora of India and neighbouring countries. He also employed native artists to illustrate novelties and these watercolour paintings are now held at Kew. Among these are some fine illustration of both cypripediums and paphiopedilums. Two from 1826 are reproduced here, namely Paphiopedilum insigne (Fig. 12) from the Khasia Hills and the Himalayan $P$. venustum. The former had earlier been sent by Wallich to London where Samuel Curtis illustrated it for John 


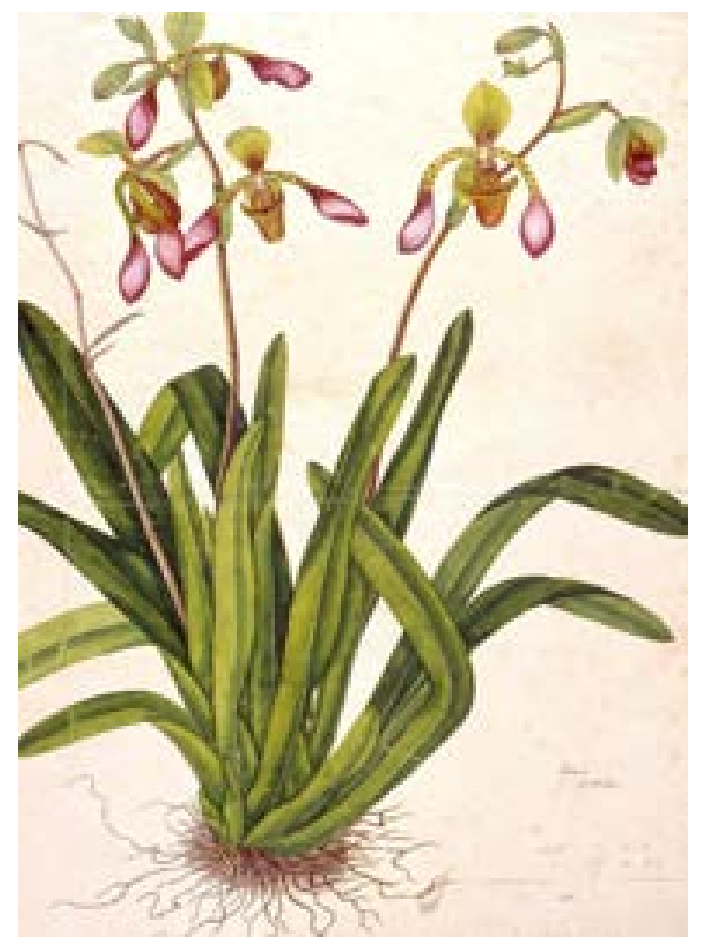

FIgURE 14. Hugh Low's painting of his collection of Paphiopedilum lowii, drawn in Sarawak, Borneo, ca. 1847. Reproduced with the kind permission of the Director and the Board of Trustees, Royal Botanic Gardens, Kew.

Lindley's Collectanea Botanica (1821) (Fig. 13).

Plant collectors occasionally illustrated the plants that they discovered. Several of these original paintings survive at Kew. Hugh Low's original watercolour of Paphiopedilum lowii (Fig. 14) also survives at Kew. The beautiful watercolours of Charles Parish, including his watercolour of the eponymous Paphiopedilum parishii, are dealt with in an accompanying article (Clayton, 2013). Many of their collections and those of other plant hunters ended up being sold by European nurseries, particularly those in England, and were illustrated when they first flowered in cultivation.

Over the past 226 years, many novelties have been first figured in the pages of Curtis's Botanical Magazine. Walter Hood Fitch, Matilda Smith, Lilian Snelling, Stella Ross-Craig, Margaret Stones, Pandora Sellars, Cristabel King and Carol Woodin have all produced outstanding illustrations of slipper orchids for the journal (Figs. 15-18). Some of Fitch's finest slipper orchid paintings were prepared for

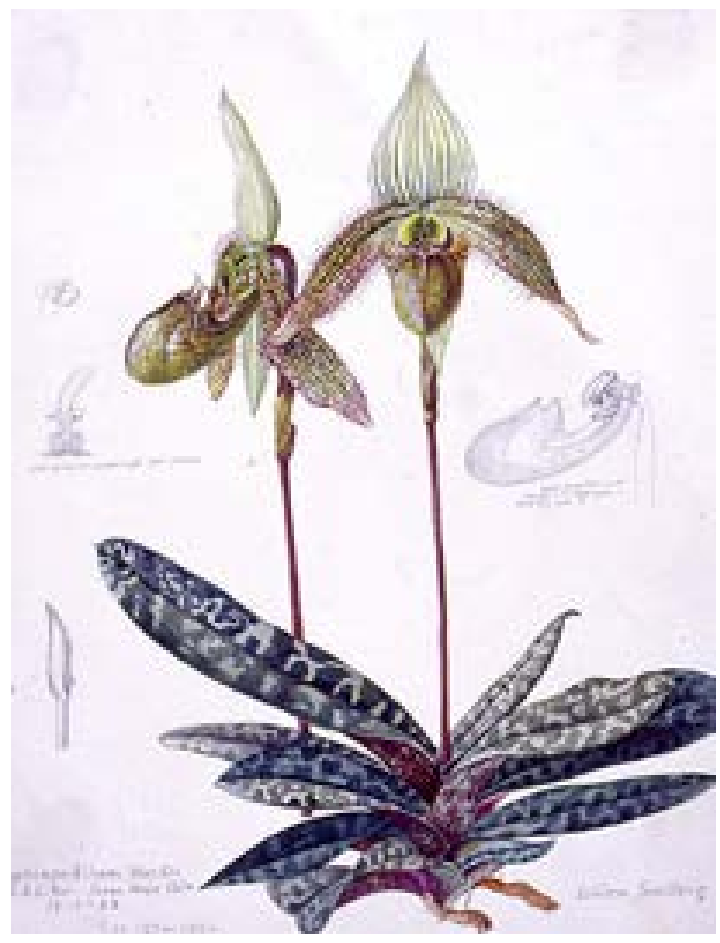

Figure 15. Lilian Snelling's Paphiopedilum callosum. Reproduced with the kind permission of the Director and the Board of Trustees, Royal Botanic Gardens, Kew.

Robert Warner's Select Orchidaceous Plants (Lovell Reeve, London: 1862-1878) (Figs. 19, 20).

Kew possesses many remarkable illustrations in its archives, none more so that John Day's 53 scrapbooks, comprising over 2800 watercolour paintings of orchids (Cribb \& Tibbs, 2004). Day cultivated and illustrated 44 species and 46 hybrid slipper orchids in three genera, Cypripedium, Paphiopedilum and Phragmipedium, in his scrapbooks. His illustrations labelled as Selenipedium and Uropedium are now considered to belong to the genus Phragmipedium, while the Southeast Asian and Indian species of Cypripedium belong to Paphiopedilum.

During Day's lifetime many species new to science were discovered and described, including thirty species of Paphiopedilum, almost half of the genus. When he successfully flowered novelties he sent them to Professor H.G. Reichenbach for identification and naming. Hence many of Reichenbach's orchid names were based on Day's plants and his specimens and drawings form part of the type materials of many species. 


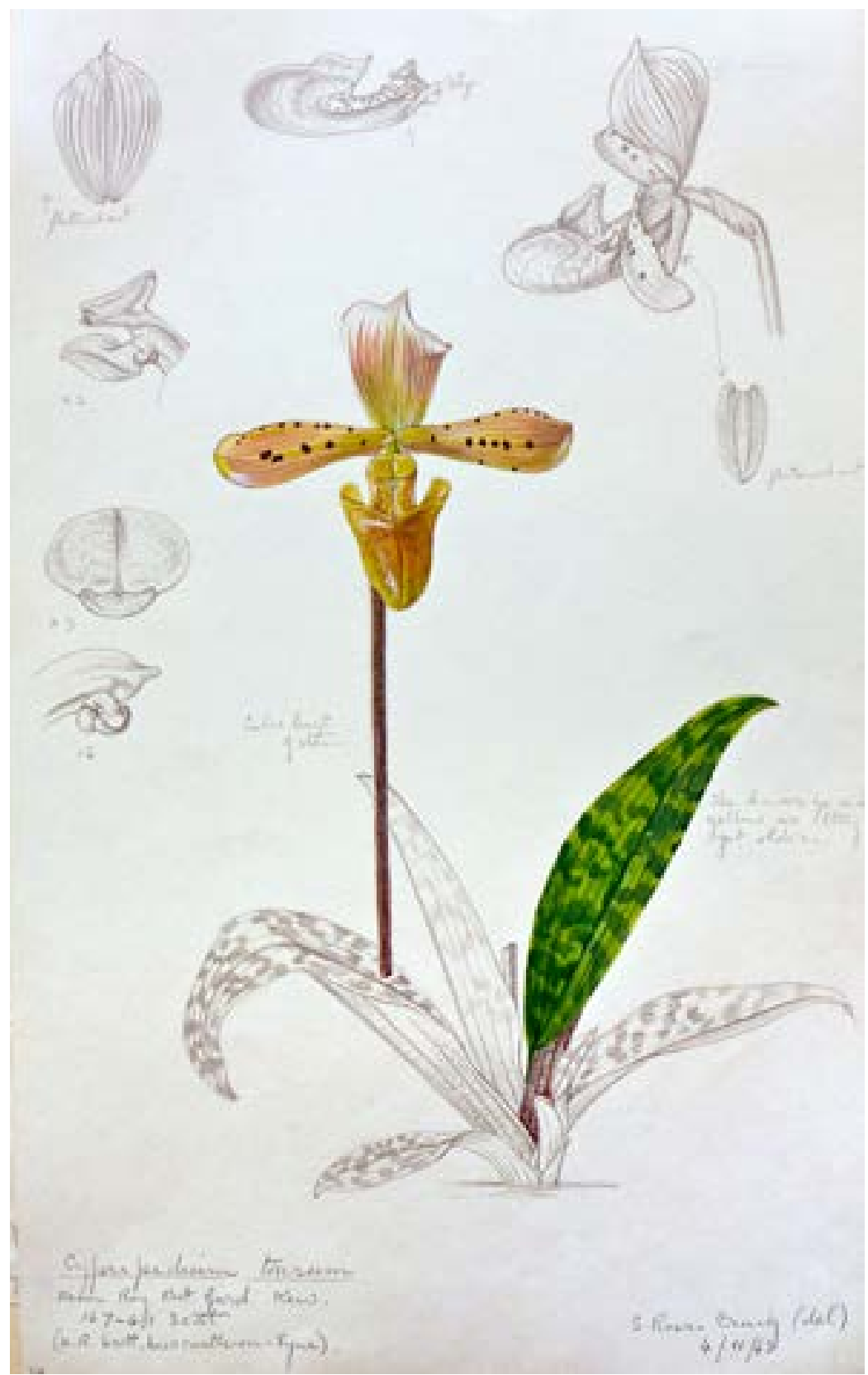

FiguRe 16. Stella Ross-Craig's Paphiopedilum tonsum. Reproduced with the kind permission of the Director and the Board of Trustees, Royal Botanic Gardens, Kew.

Some of John Day's most prized orchids were slipper orchids. Paphiopedilum dayanum (Fig. 21) was named in his honour and P. stonei (Fig. 22) after John Stone, his gardener. He was amongst the first to illustrate Paphiopedilum sanderianum (Fig. 23), one of the world's most desirable orchids. The most famous slipper orchid in his collection was Paphiopedilum stonei var. platytaenium (Fig. 24) which was also probably the most valuable plant of the day and much sought after by other growers who were willing to pay high prices for rarities and spectacular orchids. His illustration of it is one of his finest watercolours. 


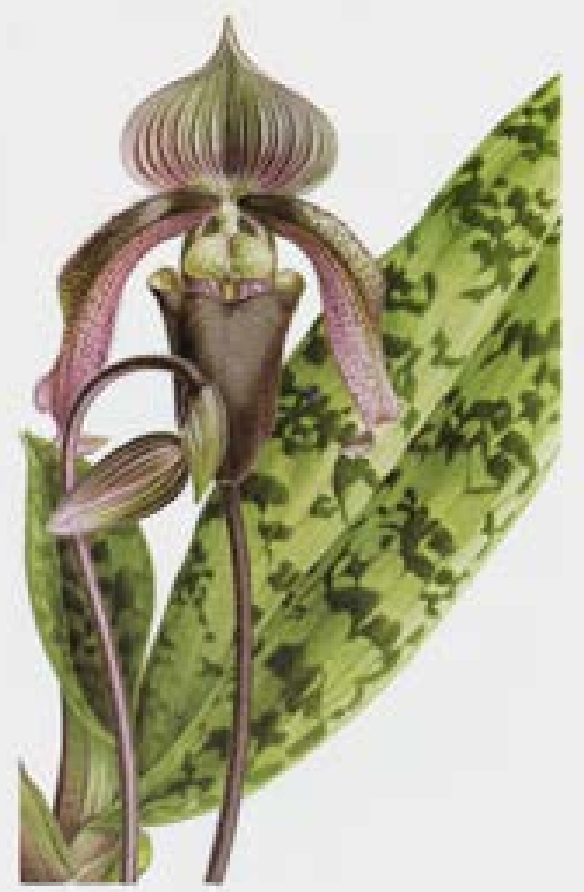

Figure 17. Pandora Sellars' Paphiopedilum superbiens. Reproduced with the kind permission of the Director and the Board of Trustees, Royal Botanic Gardens, Kew.

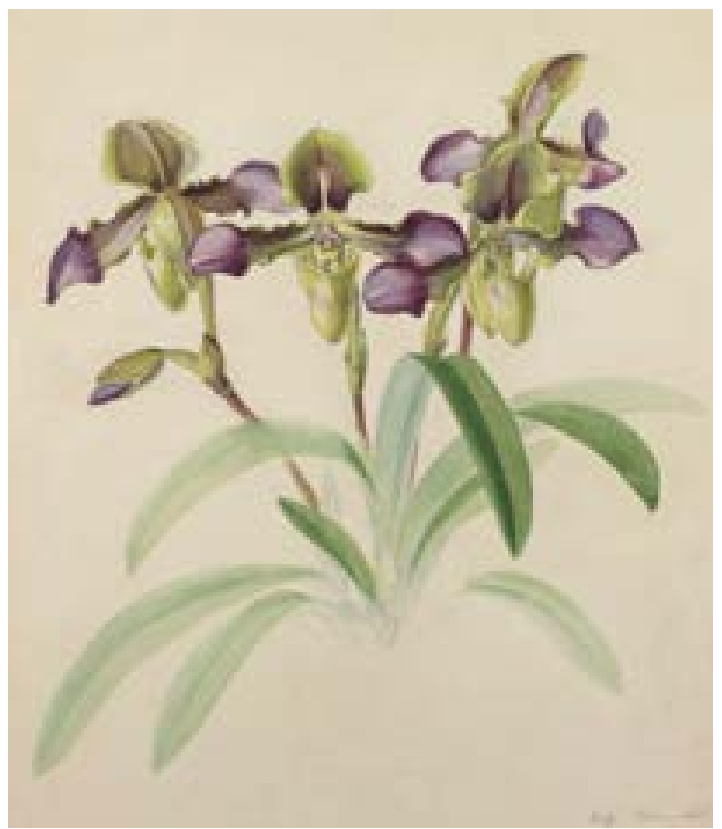

FiguRE 19. Walter Hood Fitch's Paphiopedilum hirsutissimum for Robert Warner's Select Orchidaceous Plants. Reproduced with the kind permission of the Director and the Board of Trustees, Royal Botanic Gardens, Kew.

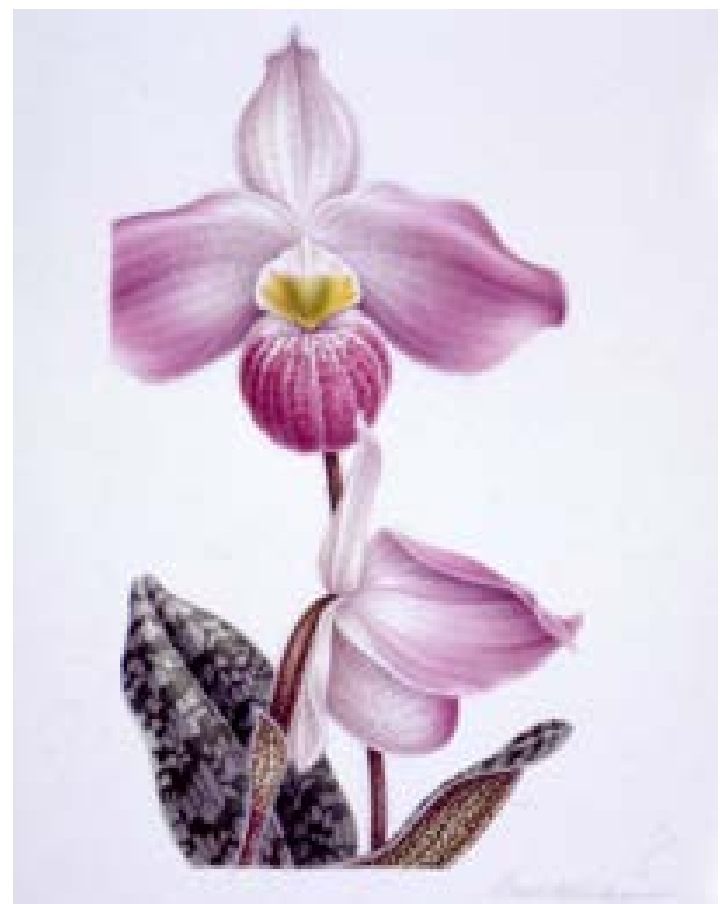

Figure 18. Carol Woodin's Paphiopedilum vietnamense. Reproduced with the kind permission of the Director and the Board of Trustees, Royal Botanic Gardens, Kew.

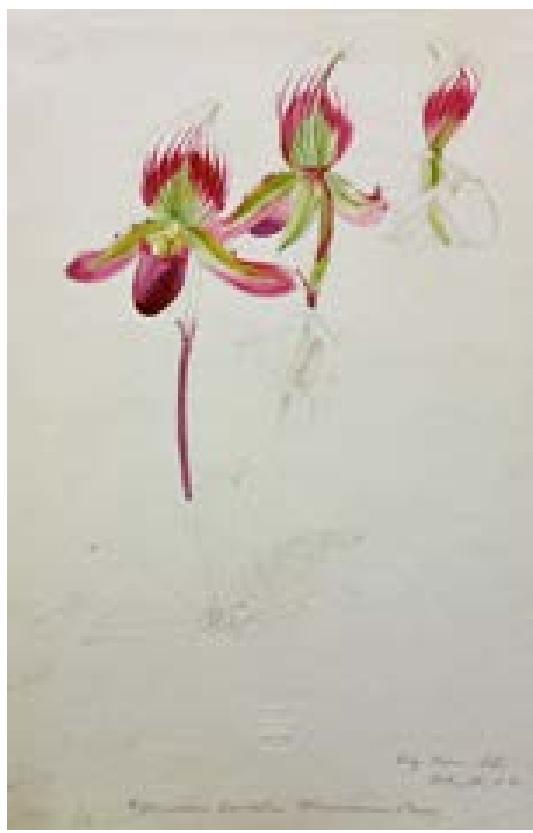

FIgURe 20. Walter Hood Fitch's Paphiopedilum callosum for Robert Warner's Select Orchidaceous Plants. Reproduced with the kind permission of the Director and the Board of Trustees, Royal Botanic Gardens, Kew. 


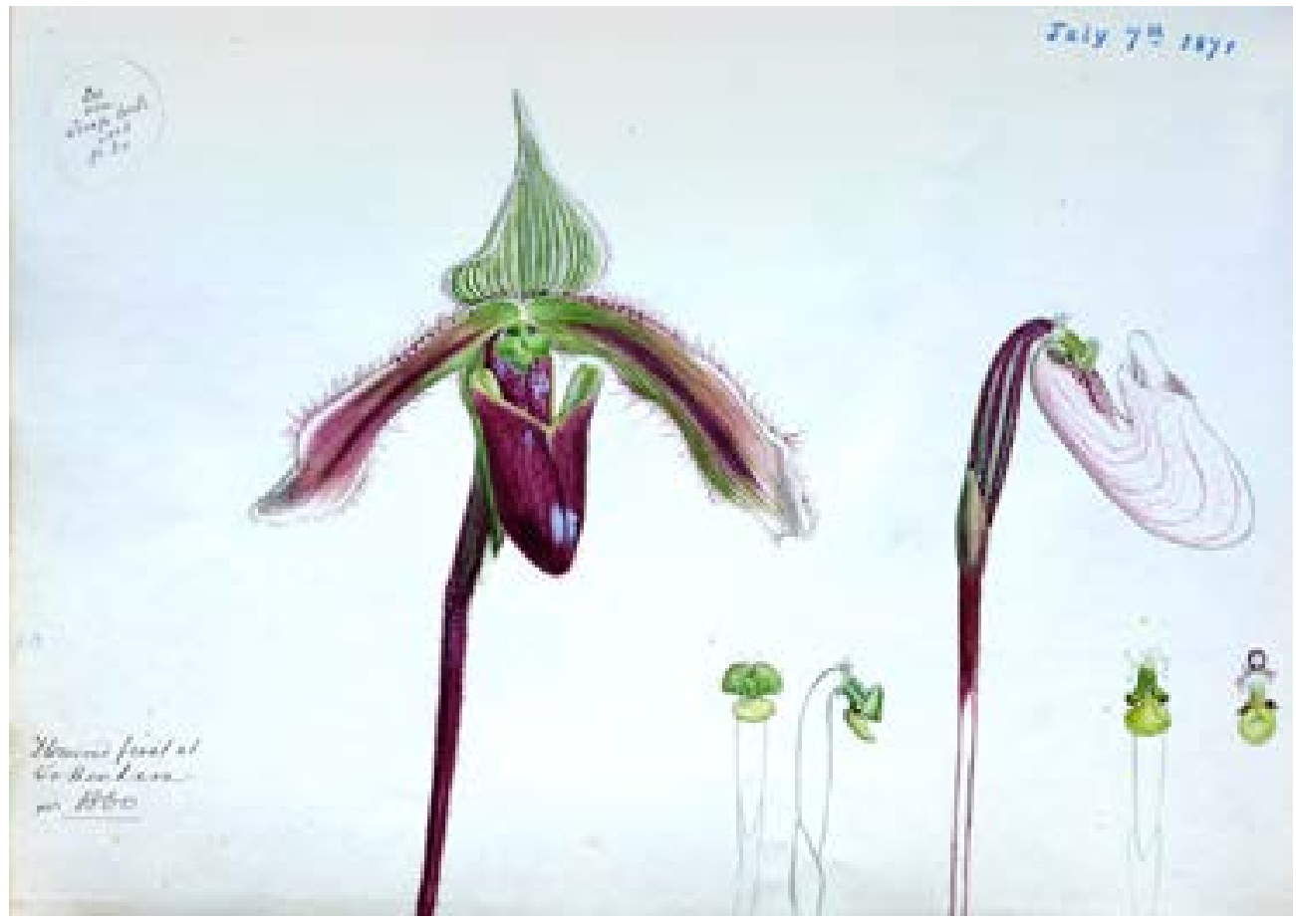

FiguRe 21. John Day's Paphiopedilum dayanum. Reproduced with the kind permission of the Director and the Board of Trustees, Royal Botanic Gardens, Kew.

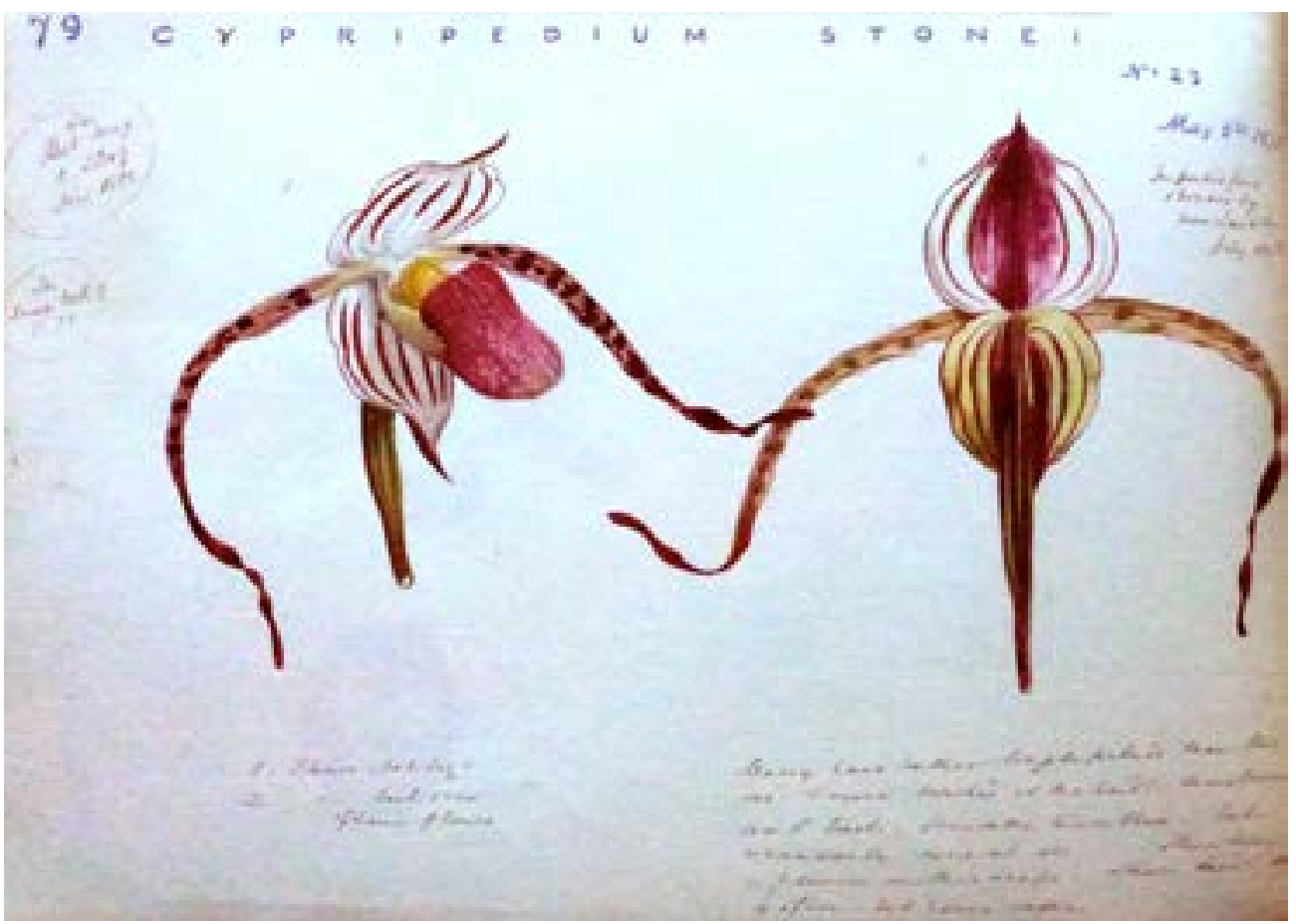

Figure 22. John Day's Paphiopedilum stonei. Reproduced with the kind permission of the Director and the Board of Trustees, Royal Botanic Gardens, Kew. 


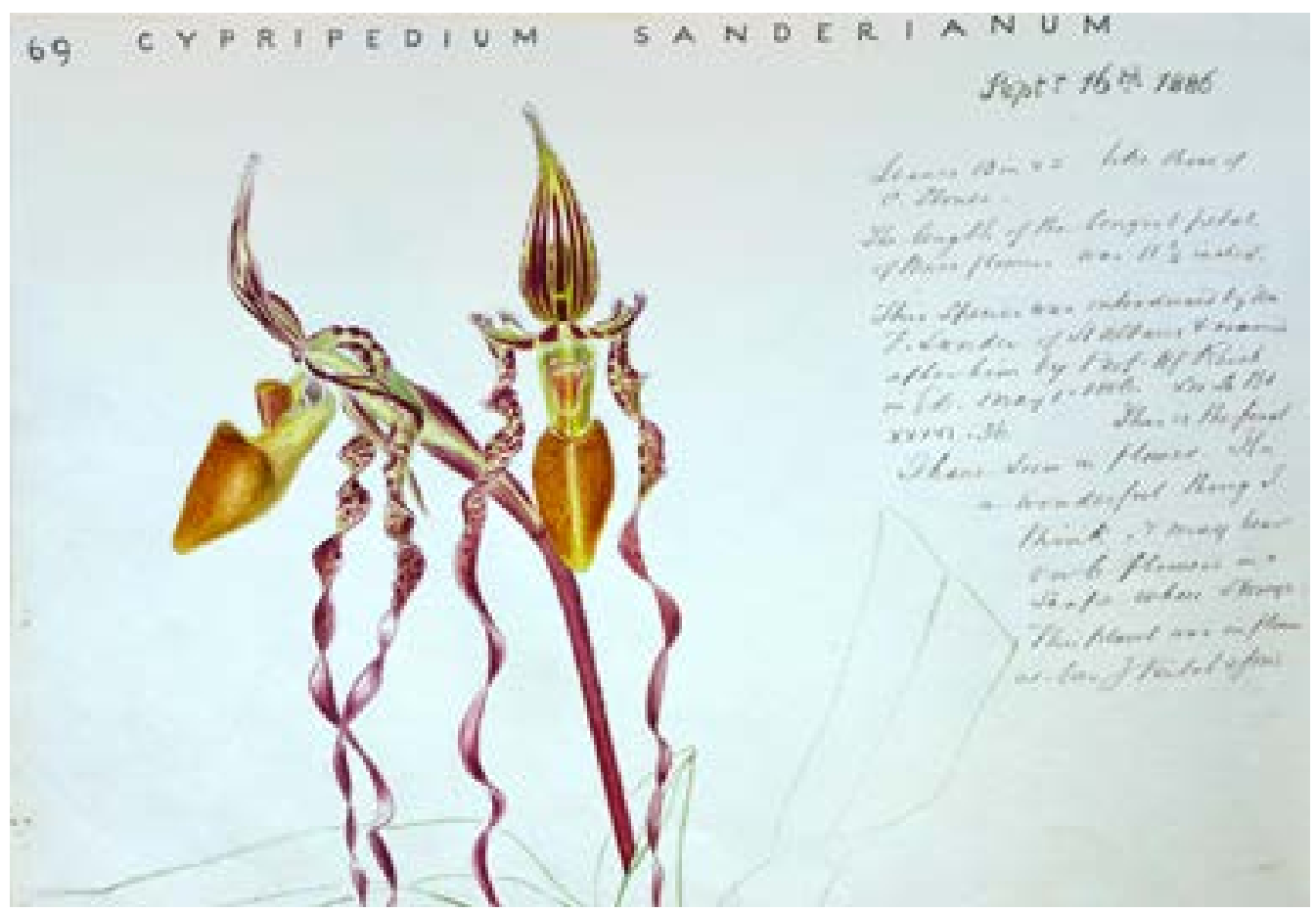

FIGURE 23. John Day's Paphiopedilum sanderianum. Reproduced with the kind permission of the Director and the Board of Trustees, Royal Botanic Gardens, Kew.

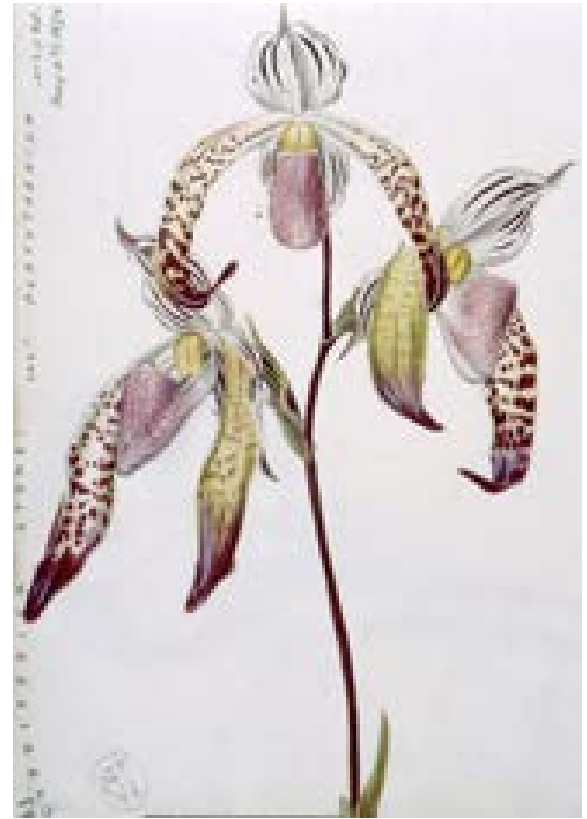

FiguRE 24. John Day's Paphiopedilum stonei var. platytaenium. Reproduced with the kind permission of the Director and the Board of Trustees, Royal Botanic Gardens, Kew.
Selenipedium and Phragmipedium - . The Spanish botanists Hippolito Ruiz López (1754-1816) and José Pavón Jiménez (1754-1840) were the first to discover and collect tropical American slipper orchids. Between 1777 and 1788, on behalf of the Spanish King Carlos III, they undertook a botanical exploration of Peru and Chile. The results of their expeditions, over 3000 collections of herbarium specimens and 2500 watercolour illustrations, formed the basis of their proposed ten-volume Florae Peruviana et Chilensis (1798-1802) of which only the first four appeared in their life-times. The illustrations, made by the artists Joseph Brunete and Isidro Gálvez, were deposited in the collections of the Royal Botanical Garden in Madrid. Amongst them are watercolours of Phragmipedium caudatum and P. boissierianum. Unfortunately, neither was described at the time by Ruiz and Pavón. John Lindley saw a flower of each that had been brought from the Ruiz and Pavón collection, still in Lima, by Matthews for Sir William Hooker. He described one as Cypripedium caudatum, but the second flower proved to be too badly preserved for description (Lindley, 1840). 


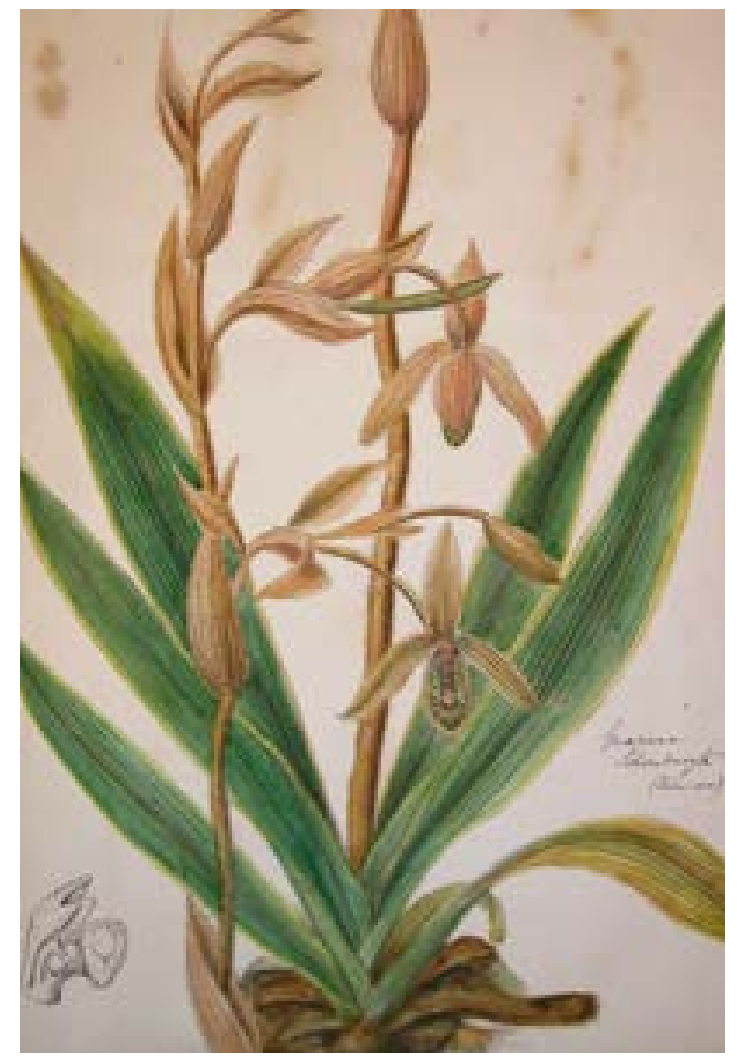

FIGURE 25. Robert Schomburgk's Phragmipedium lindleyanum, drawn on Mt Roraima, Guyana. Reproduced with the kind permission of the Director and the Board of Trustees, Royal Botanic Gardens, Kew.

Sesse and Mociño collected the first Central American Cypripedium species in Mexico between 1787 and 1803. Their collections are in the herbarium of the Royal Botanic Garden, Madrid. They collected two species to which they gave the manuscript names "C. turgidum" and "C. acuminatum". The former name was eventually published posthumously in 1890 (by which time it had already been described by La Llave \& Lexarza as C. irapeanum). The latter name, referable to Lindley's $C$. molle, has never been published. Contemporary coloured illustrations of the two Sesse \& Moçino species are preserved in the Hunt Institute collection in Pittsburg (Cribb \& Soto, 1993).

Lindley described Cypripedium lindleyanum based on a specimen collected and named by Robert Schomburgk (1804-1865) that had been collected by him near Mt Roraima in Guyana. Lindley commented at the time "I unwillingly consent, at the particular instance

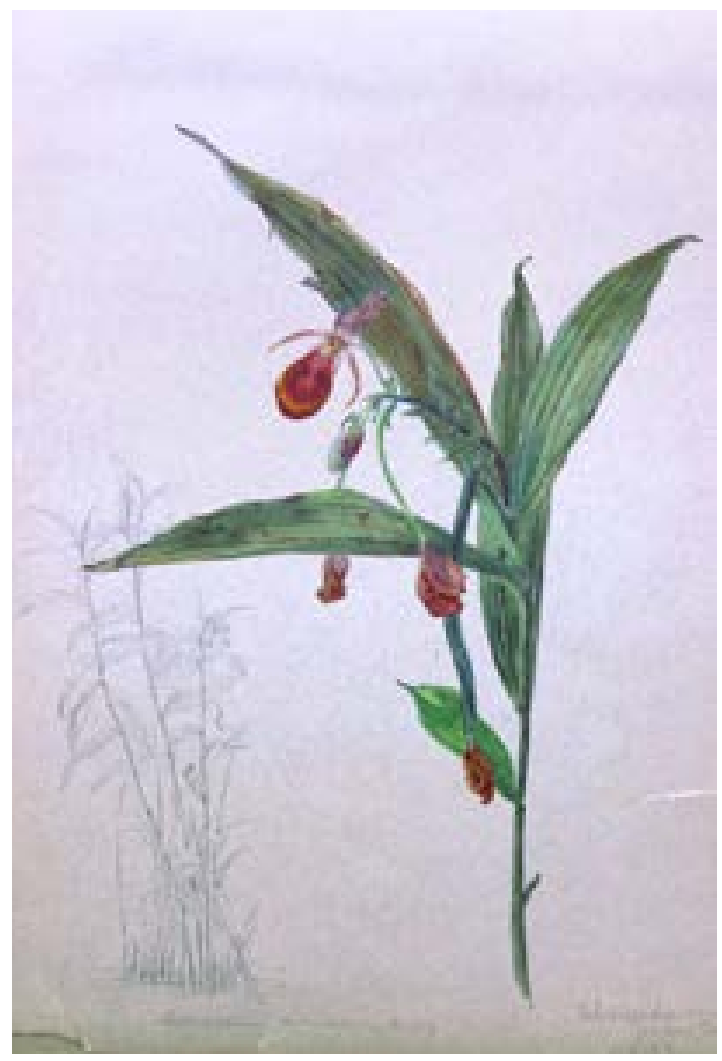

FIgURE 26. Everard Im Thurn's illustration of Selenipedium palmifolium, ca. 1884. Reproduced with the kind permission of the Director and the Board of Trustees, Royal Botanic Gardens, Kew.

of Mr Schomburgk, to allow this plant to bear my name, who have no title to the compliment". Schomburgk's original watercolour illustration (Fig. 25) remains in Lindley's herbarium at Kew. Schomburgk's adventures on Roraima were probably the inspiration for Sir Arthur Conan Doyle's Lost World (1912). A watercolour of Selenipedium palmifolium, also drawn in situ by Everard Im Thurn (1852-1932) who scaled the mountain some years later, also survives at Kew (Fig. 26).

Friedrich Lehmann (1850-1893), the prolific orchid collector in Colombia and Ecuador also painted his discoveries, probably to show European nurseries what he had to offer when he occasionally visited Europe to solicit business. His paintings of phragmipediums were published recently in this journal (Cribb, 2010).

John Day' watercolours of Phragmipedium species include early depictions of $P$. boissierianum, $P$. caudatum, P. schlimii (Fig. 27), and P. wallisii. 


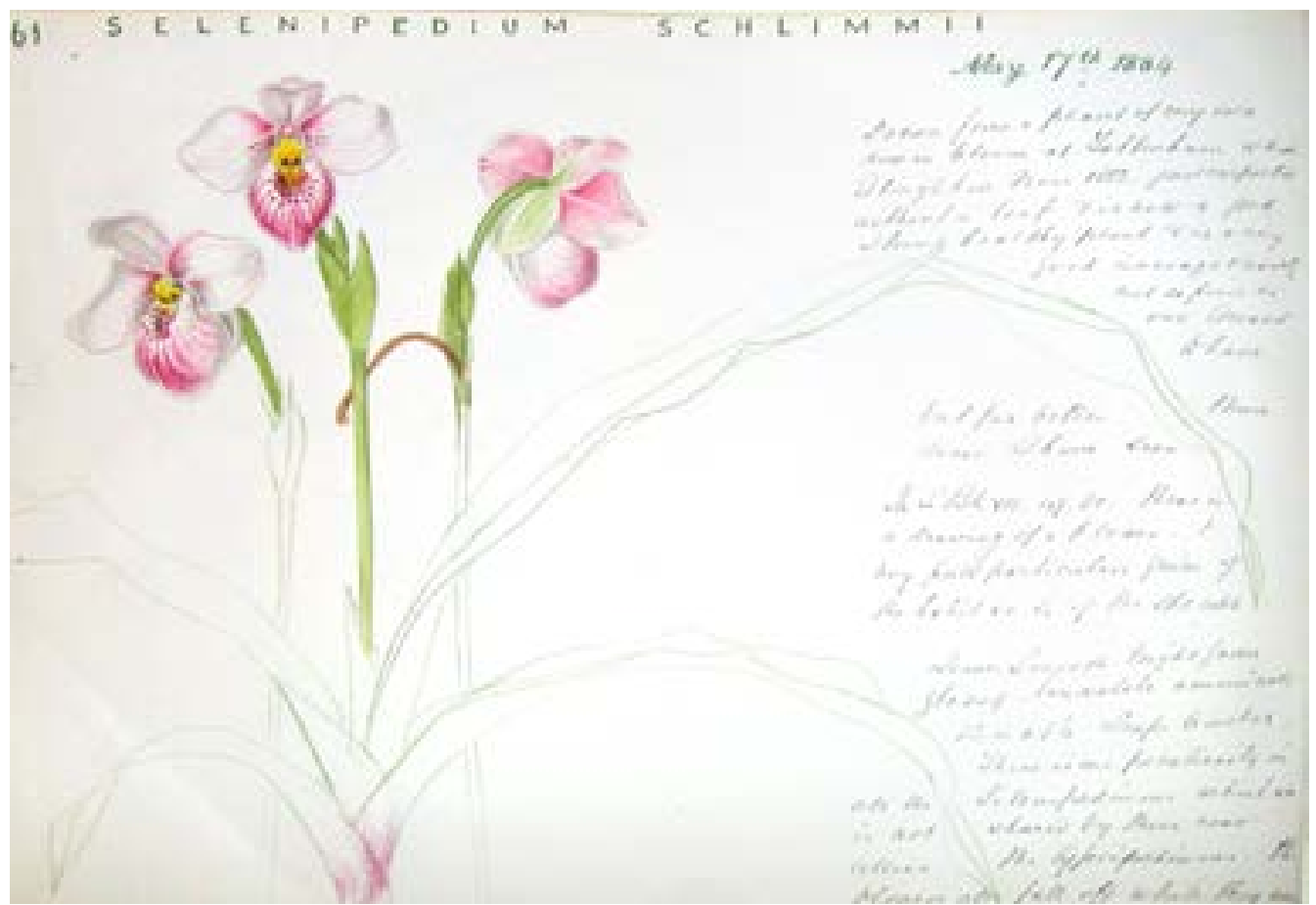

FIgURE 27. John Day's Phragmipedium schlimii. Reproduced with the kind permission of the Director and the Board of Trustees, Royal Botanic Gardens, Kew.

Artificial Hybrids - . John Day had access to, and illustrated in his scrapbooks, nearly all of the early slipper orchid hybrids raised by John Dominy and his successor John Seden for Messrs James Veitch $\&$ Sons of Exeter and Chelsea. The significance of these is considerable because systematic collections of illustrations of hybrids, for example that of the Royal Horticultural Society, did not start until the end of the 19th century when many of the early hybrids had already disappeared. Although enthusiastic about some, Day prophetically commented in his appraisal of Cypripedium (Paphiopedilum) Apiculatum, a hybrid between $P$. barbatum and P.villosum var. boxallii, that "I am afraid we shall be overcome with hybrids soon and orchids will gradually descend to the level of florist's flowers and lose their interest" (Scrap Book 51, p. 95). $\mathrm{He}$ also depicted all of the early Paphiopedilum hybrids, including $P$. Harrisianum (Fig. 28) and $P$. Morganiae (Fig. 29) and Phragmipedium hybrids, including $P$. Dominii (Fig. 30), P. Sedenii (Fig. 31), $P$. Cardinale and others in their first flowering at the Veitch nursery in Chelsea.
Thus, Day's paintings of the early hybrids are an invaluable record of English nurseries early ventures in orchid breeding. His pioneering work on illustrating hybrids was taken up by the Royal Horticultural Society which has employed a series of artists to paint awarded orchids for over a century, a collection that now includes many images of slipper and other orchids and a tradition that endures to the present day (Figs. 32). It seems likely that the idea for the RHS illustrations came from the common practice of orchid nurseries equipping their salesmen who sold orchids around the country with sets of watercolour paintings of their best clones so that growers could order plants based on the paintings. Some of these samples survive at Kew, such as that of Paphiopedilum W.R. Lee and $P$. Morganiae (Fig. 33).

Conclusion. Slipper orchids have been a popular subject for botanical artists for over four centuries and remain so today. Their unusual and often showy three-dimensional flowers are an artistic challenge, but the resulting images are often striking and far easier to interpret than descriptions, thereby facilitating 


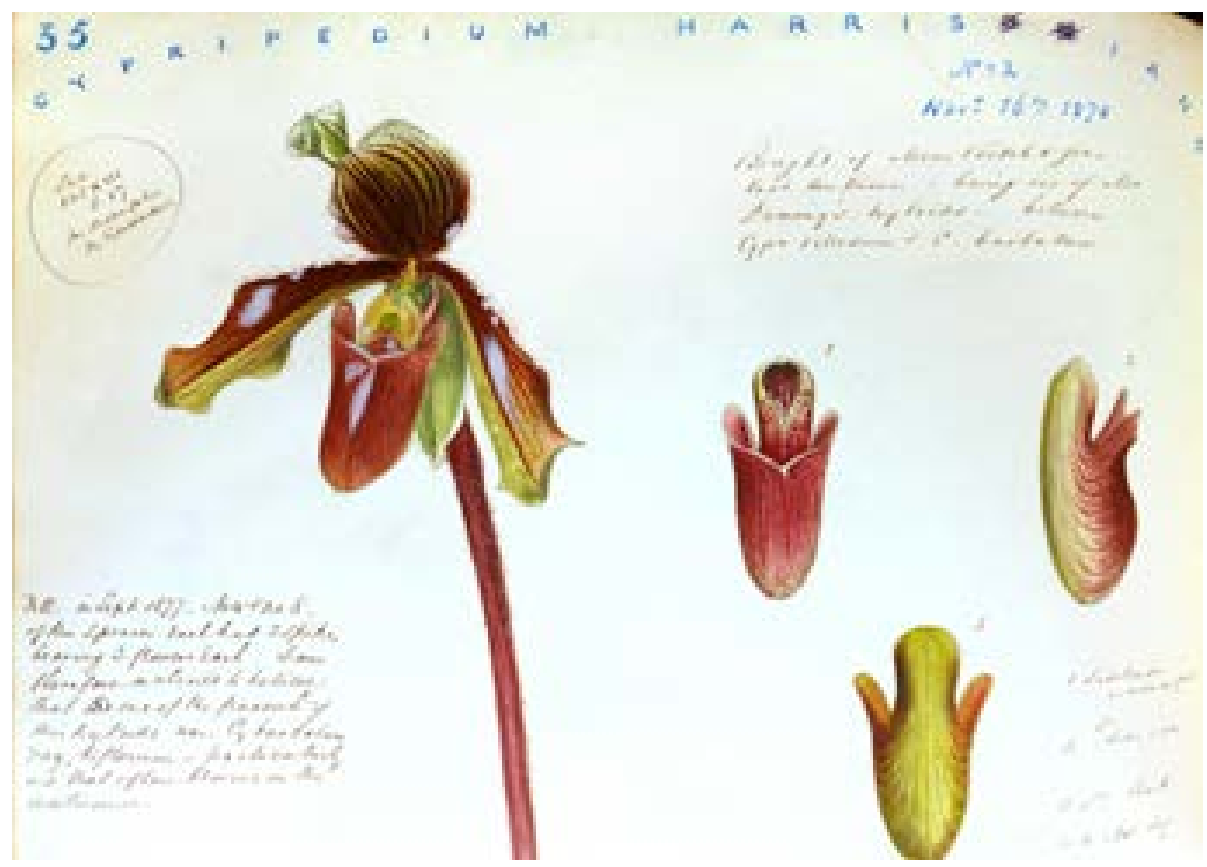

Figure 28. John Day's Paphiopedilum Harrisianum. Reproduced with the kind permission of the Director and the Board of Trustees, Royal Botanic Gardens, Kew.

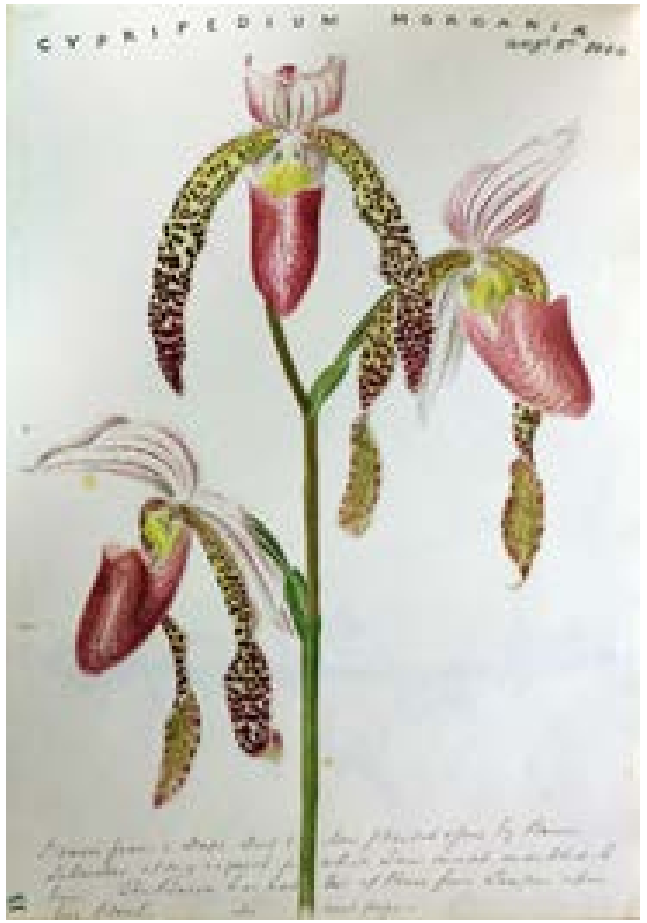

Figure 29. John Day's Paphiopedilum Morganiae. Reproduced with the kind permission of the Director and the Board of Trustees, Royal Botanic Gardens, Kew.

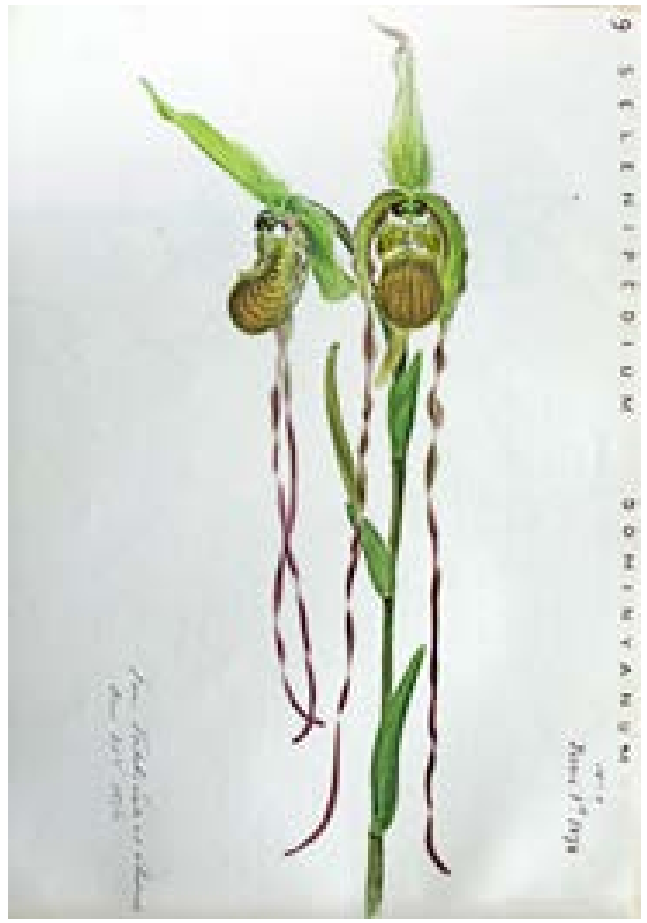

FiguRE 30. John Day's Phragmipedium Dominianum. Reproduced with the kind permission of the Director and the Board of Trustees, Royal Botanic Gardens, Kew. 


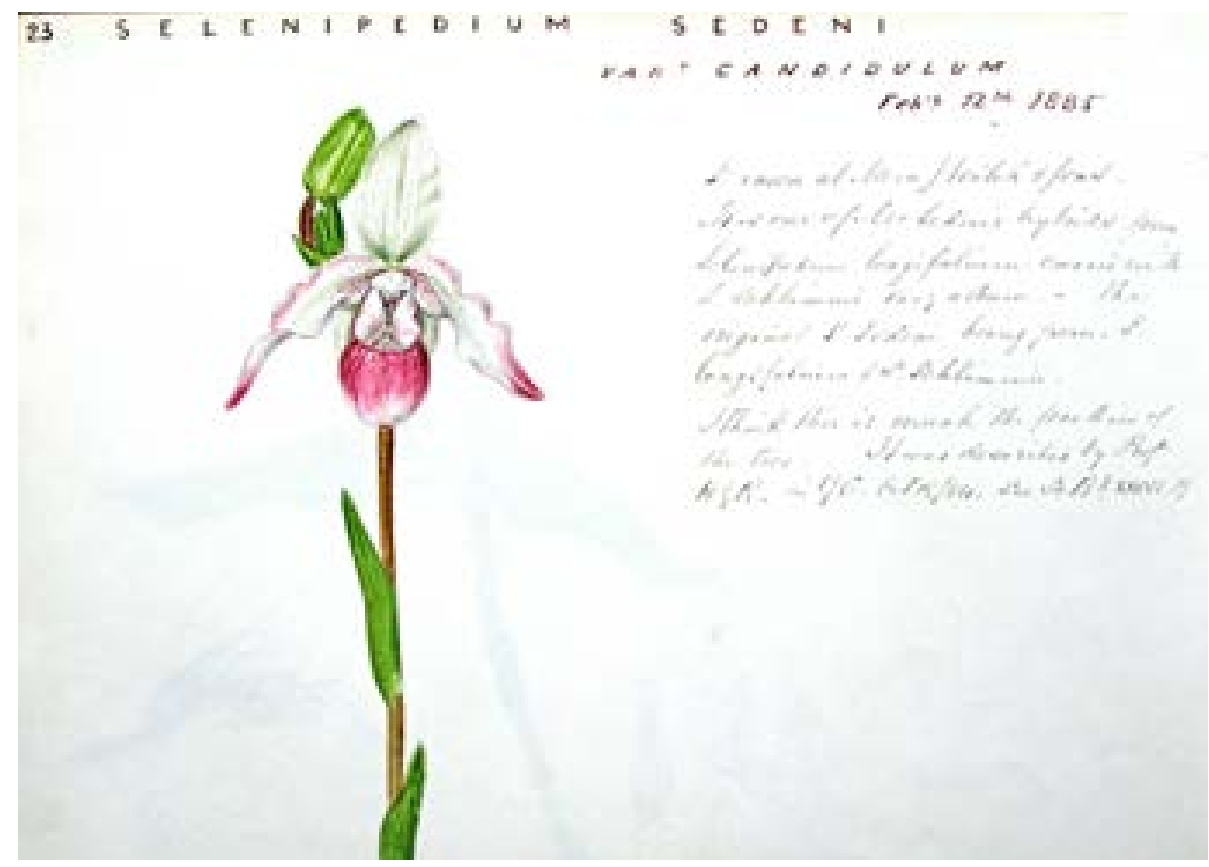

Figure 31. John Day's Phragmipedium Sedenii. Reproduced with the kind permission of the Director and the Board of Trustees, Royal Botanic Gardens, Kew.

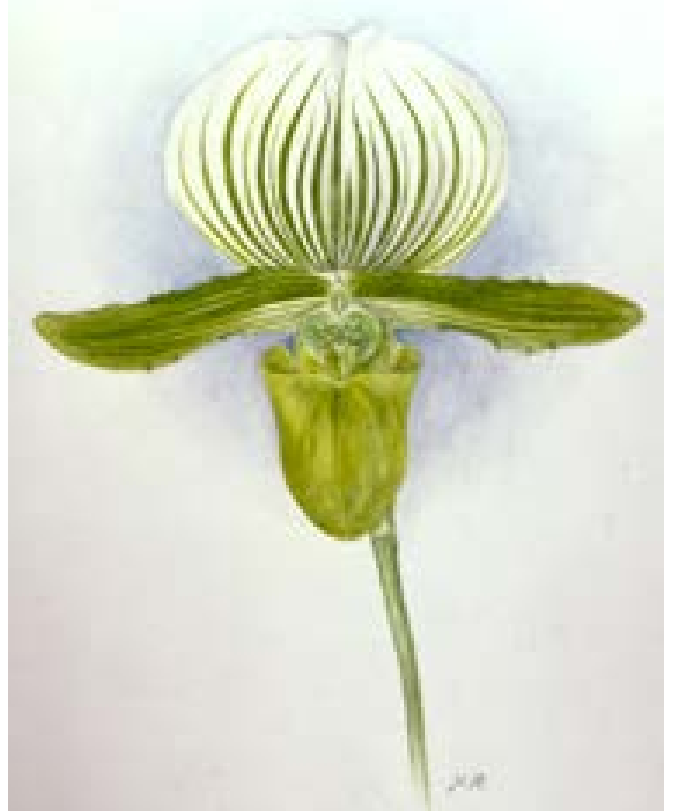

FIGURE 32. Paphiopedilum lawrenceanum var. hyeanum by Nellie Roberts for the Royal Horticultural Society. Reproduced with the kind permission of the Director and the Board of Trustees, Royal Botanic Gardens, Kew.

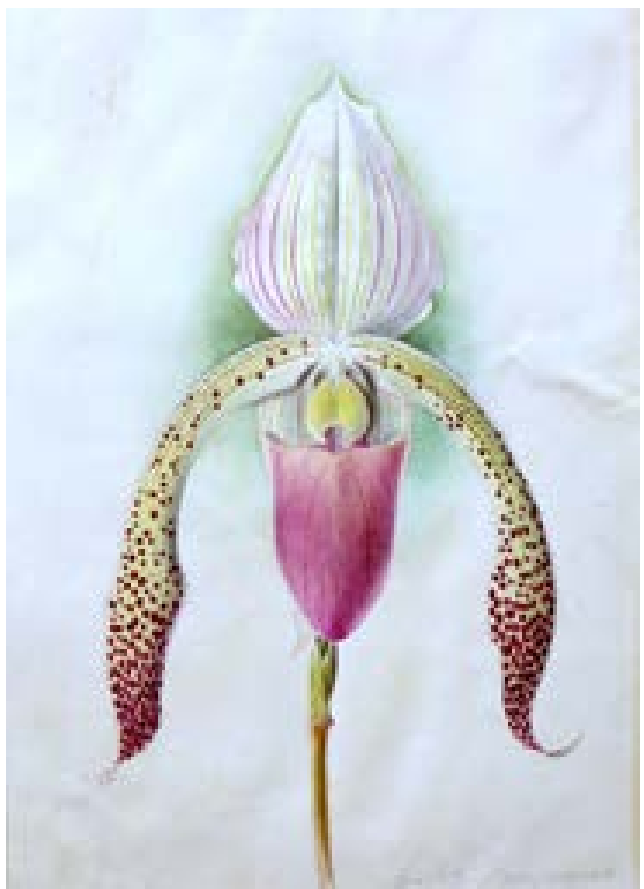

FIGURE 33. Trade painting of Phragmipedium Morganiae from the late Victorian period. Reproduced with the kind permission of the Director and the Board of Trustees, Royal Botanic Gardens, Kew. 


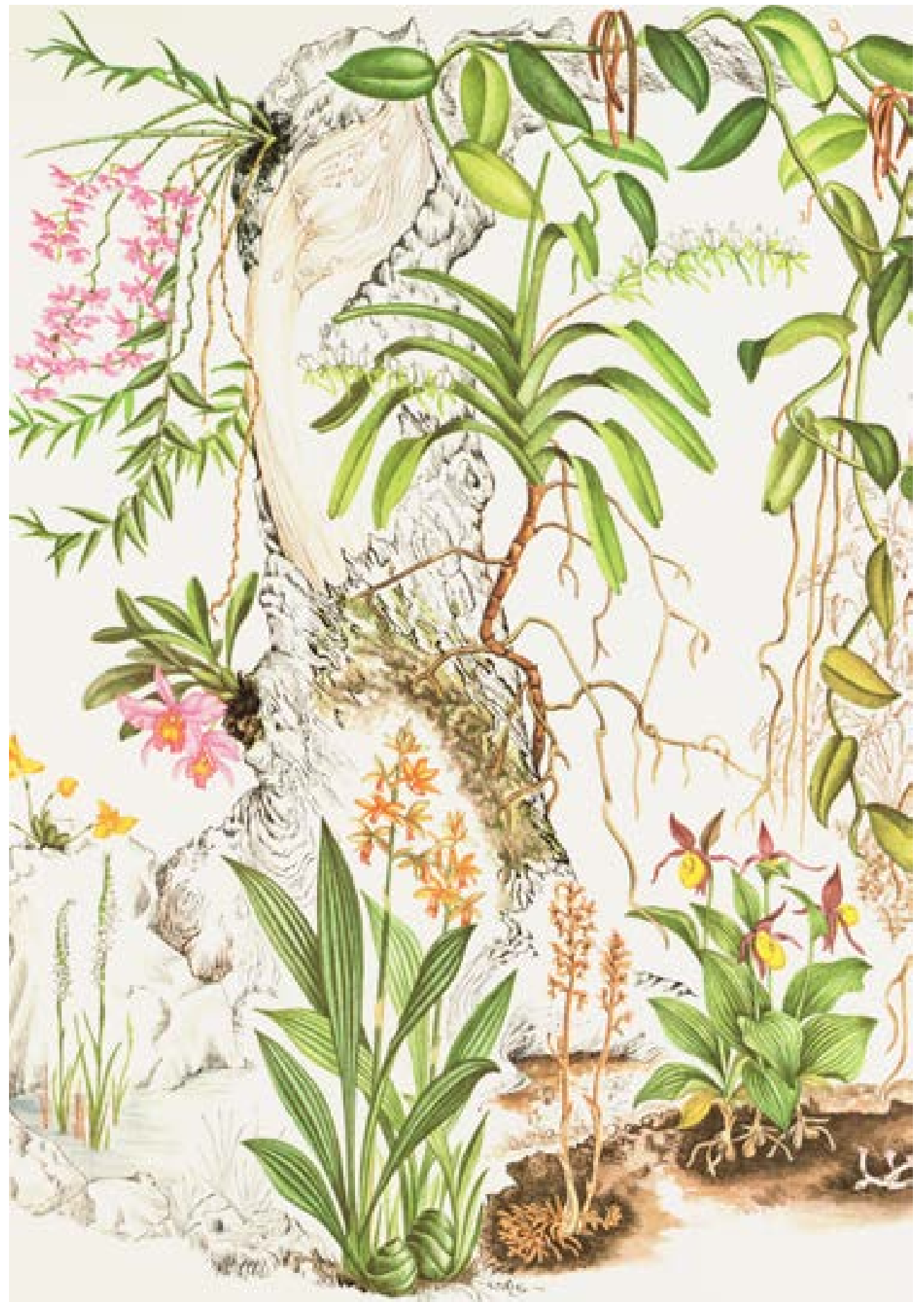

Figure 34. Mary Grierson's Cypripedium calceolus for P. Francis Hunt's Orchidaceae (Bourton Press, Bourton. 1973). 
identification and naming. Nowadays, most species have been illustrated many times, occasionally inaccurately as in Mary Grierson's painting of Cypripedium calceolus (Fig. 34) for Peter Hunt's Orchidaceae which endows it with tubers!

The history of their discovery and introduction into cultivation can be traced through the chronology of their depiction. The archives also can be used to trace the development of artificial breeding of slipper orchids for the horticultural trade, through collections of paintings by enthusiasts, for example, John Day and by the artists employed to illustrate awarded plants by the Royal Horticultural Society in London.

In recent years the popularity of botanical art has reached a level not previously seen since Victorian times. Watercolour paintings of slipper orchids are popular and fetch significant prices at art shows.

Slipper orchids have also been used to illustrate the cover of foodstuffs, such as ice cream and chocolates. However, it is probable that the most lucrative line for slipper orchid illustration is for postage stamp issues. Cypripedium calceolus, the Eurasian lady's slipper, has appeared on the stamps of numerous countries, including most European countries, the United Nations and, surprisingly the Grenadines of St Vincent in the Caribbean. Tropical slipper orchid species and hybrids are also popular subject for stamp issues. The small island of Jersey, for example, has produced stamps featuring both Paphiopedilum hybrids and the Peruvian Phragmipedium besseae.

ACKNOWLEDGEMENTS. I would like to thank Marilyn Ward and Julia Buckley for their help in sourcing illustrations at Kew; Dr. Margret Ribbert, Curator of the Historisches Museum Basel; and Samuel Sprunger and Werner Lehmann of the Swiss Orchid Foundation for alerting me to the image on the tapestry.

\section{LiTERATURE CITED}

Aiton, W. 1789. Hortus Kewensis. G. Nicol, London.

Albert, V. A. 1994. Cladistic relationships of the slipper orchids (Cypripedioideae: Orchidaceae) from congruent morphological and molecular data. Lindleyana 9(2): 115-132.

Albert, V. A. \& M. W. Chase. 1992. Mexipedium: a new genus of slipper orchids (Cypripedioideae: Orchidaceae). Lindleyana 7: 172-176.
Amman, J. 1741. Quinque nova plantarum genera. Science Academy, St Petersburg.

Arber, A. 1986. Herbals and their origin and evolution. 3rd ed. Cambridge University Press.

Blunt, W. \& W. Stearn. 1994. The Art of Botanical Illustration. Antique Collectors Club, Woodbridge, Suffolk.

Blume, C. L. 1858. Collection des orchidées les plus remarquable de l'Archipel Indien et du Japon. G.C. Sulpke, Amsterdam.

Catesby, M. 1754. The Natural History of Carolina, Florida and the Bahama Islands.

Chase, M. W., K. M. Cameron, R. L. Barrett \& J. V. Freudenstein. 2003. DNA data and Orchidaceae systematics: a new phylogenetic classification. In Dixon, K.W., S. P. Kell, R. L. Barrett \& P. J. Cribb (eds.), Orchid Conservation: 69-89. Natural History Publications, Kota Kinabalu, Sabah.

Chen, S.C., Z. H. Liu, L. J. Chen \& L. Q. Li. 2013. The genus Cypripedium in China. Science Press, Beijing.

Cornut, J. P. 1635. Canadensium Plantarum Historia. S. le Moyne, Paris.

Cribb, P. J. 1992. The Chinese spotted-leaved cypripediums. Bull. Alp. Gard. Soc. 60, 2: 165-177.

Cribb, P. J. 2010. The life and travels of Friedrich Carl Lehmann. Lankesteriana 10, 2-3: 9-30.

Cribb, P.J. \& S. C. Chen. 1994. Further thoughts on the Chinese spotted-leaved cypripediums. Orchid Rev. 102: 321-323.

Cribb, P.J. \& M. A. Soto. 1993. The genus Cypripedium in Mexico and Central America. Orquidea (Mexico) 13, 1-2: 205-214.

Cribb P.J. \& M. Tibbs. 2004) $A$ very Victorian passion. The orchid paintings of John Day. Thomas Nelson, London.

Dodoens, R. 1568 Florum, et coronarium odoratarumque nonnullarum herbarium historia.

Dressler, R.L. 1981. The Orchids. Natural History and Classification. Harvard University press.

Dressler, R.L. 1993. Phylogeny and classification of the orchid family. Cambridge University Press.

Farr, E. R., J. A. Leussink, \& F. A. Stafleu. 1979. Index nominum genericorum. Bohn, Scheltema \& Holkema, Utrecht; Junk, The Hague.

Gmelin, J. G. 1747-1749. Flora Sibirica, sive Historiae plantarum Sibiriae. Science Academy, St Petersburg.

Iinuma, Y. 1874. Somoku Dzusetsu, ed. 2. Mino, Ogakai.

Linnaeus, C. 1737. Flora Lapponica. Amsterdam.

Linnaeus, C. 1753. Species Plantarum. L. Salvius, Stockholm.

Miller, P. 1731. Gardeners Dictionary. C. Rivington, London.

Parkinson, J. (1640). Theatrum botanicum. T. Cotes, 
Parkinson, J. 1640. Theatrum botanicum. T. Cotes, London. Pavord, A. (2005). The naming of names, the search for order in the world of plants. Bloomsbury, London.

Pfitzer, E. (1886). Morphologische studien über die Orchideenblüthe. C. Winter, Heidelberg.

Pfitzer, E. (1889). Orchidaceae. In Engler, A., \& Prantl, C. eds. Die natürlichen Pflanzenfamilien 2, 6. W. Engelmann, Leipzig.

Pfitzer, E. (1894). Übersicht des natürlichen systems der Pflanzen. C. Winter, Heidelberg.

Pridgeon, A., P. J. Cribb, M. W. Chase \& F. Rasmussen (eds.). 1999. Genera orchidacearum vol. 1. Oxford University Press.

Rafinesque, C. S. 1819. Prodrome des nouveaux genre des plantes. J. Phys. Chim. Hist. Nat., 89: 96-107.
Rafinesque, C. S. 1838. Flora telluriana. C. Rafinesque, Philadelphia.

Reichenbach, H. G. 1854. Xenia orchidacea, vol. 1. Brockhaus, Leipzig.

Rolfe, R. A. 1896. The Cypripedium group. Orchid Rev. 4: 327-334, 363-367.

Schmiedel, D. C. C. (ed.) 1754-1759. Conradi Gesneri... Opera Botanica. J.M. Seligmann, Norimberg.

Soto, M. A., G. A. Salazar \& E. Hagsater. 1990. Phragmipedium xerophyticum, a new species from south-east Mexico. Orquidea (Mexico) 12, 1: 1-10.

Zoller, H., M. Steinmann \& K. Schmidt. 1972-1980. Conradi Gesneri Historia plantarum. Urs Graf, Dietikon, Zürich. 